\title{
Reconstructions of biomass burning from sediment-charcoal records to improve data-model comparisons
}

\author{
Jennifer R. Marlon ${ }^{1}$, Ryan Kelly ${ }^{2}$, Anne-Laure Daniau ${ }^{3}$, Boris Vannière ${ }^{4}$, Mitchell J. Power ${ }^{5}$, Patrick Bartlein ${ }^{6}$, \\ Philip Higuera $^{7}$, Olivier Blarquez ${ }^{8}$, Simon Brewer ${ }^{5}$, Tim Brücher ${ }^{9}$, Angelica Feurdean ${ }^{10,11}$, Graciela Gil Romera ${ }^{12}$, \\ Virginia Iglesias $^{4}$, S. Yoshi Maezumi ${ }^{13}$, Brian Magi ${ }^{14}$, Colin J. Courtney Mustaphi ${ }^{15}$, and Tonishtan Zhihai ${ }^{16}$ \\ ${ }^{1}$ School of Forestry and Environmental Studies, Yale University, New Haven, USA \\ ${ }^{2}$ Neptune and Company, Inc., Lakewood, CO, USA \\ ${ }^{3}$ Centre National de la Recherche Scientifique (CNRS), Environnements et Paléoenvironnements Océaniques et Continentaux \\ (EPOC), Unité Mixte de Recherche (UMR) 5805, Université de Bordeaux, 33615 Pessac cedex, France \\ ${ }^{4}$ Chrono-environnement UMR6249 and MSHE USR3124, CNRS, Univ. Bourgogne Franche-Comté, \\ 25000 Besançon, France \\ ${ }^{5}$ Department of Geography, Natural History Museum of Utah, University of Utah, Salt Lake City, USA \\ ${ }^{6}$ Department of Geography, University of Oregon, Eugene, USA \\ ${ }^{7}$ College of Forestry and Conservation, University of Montana, Missoula, USA \\ ${ }^{8}$ Département de Géographie, Université de Montréal, Montréal, Québec \\ ${ }^{9}$ GEOMAR Helmholtz Centre for Ocean Research Kiel, Düsternbrooker Weg 20, Kiel, Germany \\ ${ }^{10}$ Senckenberg Biodiversity and Climate Research Centre (BiK-F), Frankfurt am Main, Germany \\ ${ }^{11}$ Department of Geology, Babeş-Bolyai University, Cluj-Napoca, Romania \\ ${ }^{12}$ IPE-CSIC, Zaragoza, Spain \\ ${ }^{13}$ Department of Archaeology, University of Exeter, Exeter, UK \\ ${ }^{14}$ Department of Geography and Earth Sciences, University of North Carolina at Charlotte, Charlotte, USA \\ ${ }^{15}$ Environment Department, University of York, York, UK \\ ${ }^{16}$ State Key Laboratory of Loess and Quaternary Geology, Key Laboratory of Aerosol Chemistry and Physics, Institute of \\ Earth Environment, Chinese Academy of Sciences, Xi'an, Shaanxi 710075, PR China
}

Correspondence to: Jennifer R. Marlon (jennmarlon@gmail.com)

Received: 25 September 2015 - Published in Biogeosciences Discuss.: 18 November 2015

Revised: 17 April 2016 - Accepted: 2 May 2016 - Published: 3 June 2016

\begin{abstract}
The location, timing, spatial extent, and frequency of wildfires are changing rapidly in many parts of the world, producing substantial impacts on ecosystems, people, and potentially climate. Paleofire records based on charcoal accumulation in sediments enable modern changes in biomass burning to be considered in their long-term context. Paleofire records also provide insights into the causes and impacts of past wildfires and emissions when analyzed in conjunction with other paleoenvironmental data and with fire models. Here we present new 1000-year and 22000 -year trends and gridded biomass burning reconstructions based on the Global Charcoal Database version 3 (GCDv3), which includes 736 charcoal records (57 more than in version 2 ). The
\end{abstract}

new gridded reconstructions reveal the spatial patterns underlying the temporal trends in the data, allowing insights into likely controls on biomass burning at regional to global scales. In the most recent few decades, biomass burning has sharply increased in both hemispheres but especially in the north, where charcoal fluxes are now higher than at any other time during the past 22000 years. We also discuss methodological issues relevant to data-model comparisons and identify areas for future research. Spatially gridded versions of the global data set from GCDv3 are provided to facilitate comparison with and validation of global fire simulations. 


\section{Introduction}

Fire has long been recognized as an important ecological process because of its influence on species distributions and role in shaping other key ecosystem properties (Bond and Keeley, 2005). Fire also affects regional and global biogeochemical and hydrologic cycles (Shakesby and Doerr, 2006; van der Werf et al., 2006), geophysical processes (Morris and Moses, 1987; DeBano, 2000), and the climate system (Randerson et al., 2006; Ward et al., 2012; Saleh et al., 2014). Nevertheless, large gaps remain in our understanding of the interactions between fire and climate, despite an increasing need to manage fire and its emissions (Keywood et al., 2013).

Fire activity has been characterized at a wide range of spatial and temporal scales using field observations and historical data (e.g., Mouillot and Field, 2005; Gavin et al., 2007), dendrochronological data (e.g., Falk et al., 2011), satellites (e.g., Mouillot et al., 2014), ice cores (e.g., McConnell et al., 2007), and charcoal deposits in sediments, peat bogs, swamps, soils, and other environments (e.g., Whitlock and Bartlein, 2004). Sedimentary records are unique among these data sources because of the broad temporal and spatial coverage they provide, which includes reconstructions of fire history at local to global spatial scales and decadal to millennial temporal scales (e.g., Carcaillet et al., 2002; Brown, 2005; Marlon et al., 2008; Iglesias and Whitlock, 2014).

Results from paleofire research have helped lay a foundation for understanding the linkages among fire, climate, vegetation change, and human activities across a broad range of temporal and spatial scales. Fire-history data from sediment records highlight the importance of fire as a force of longterm global environmental change. Syntheses of data in the Global Charcoal Database (GCD), for example, reveal important variations in biomass burning during the last glacial period (Daniau et al., 2010), the last 21000 years (Power et al., 2008; Daniau et al., 2012), and the last 2000 years (Marlon et al., 2008). With the increasing number of sites in the GCD, regional syntheses became possible, including longterm analyses of climate and human influences on burning in Australasia (Mooney et al., 2011; Williams et al., 2015), the Mediterranean (Colombaroli et al., 2009; Vanniere et al., 2011), the western USA (Marlon et al., 2012), and the Americas more broadly (Whitlock et al., 2007; Power et al., 2012).

Here we briefly review the history of biomass burning reconstructions based on charcoal data, and we introduce version 3 of the GCD (GCDv3, $n=736$ ), which improves on GCDv1 (Power et al., 2008) and GCDv2 (Daniau et al., 2012) by adding 57 records. We also present the GCDv3 in a new globally gridded format along with several broad-scale syntheses created using the open-source paleofire R package (Blarquez et al., 2014). The new gridded maps illustrate the spatial and temporal variability in fire activity over the past 22000 years, highlighting recent departures from the longterm trends. The maps should be useful for modelers as well as others in the Earth sciences, particularly given the wide- ranging impacts of fire. Finally, we review several important limitations to charcoal-based records and identify promising future directions for the field.

\section{Reconstructing fire history with sediment-charcoal data}

Fire-history research based on sediment-charcoal data has advanced rapidly in recent decades. Early analyses of sedimentary charcoal were typically conducted to support studies focused primarily on reconstructing past vegetation changes (Heusser, 1995; Fuller et al., 1998; Haberle, 1998; Behling, 2001). A few early studies focused more directly on fire (Swain, 1973; Burney, 1987; Delcourt et al., 1998). In many cases, microscopic $(<100 \mu \mathrm{m})$ charcoal particles were tallied alongside pollen grains. Pollen and charcoal particles were converted to concentrations using the abundance of exotic markers of a known quantity added to each sample, and charcoal data were presented as ratios of the relative abundance of charcoal to pollen. Records were usually sampled at low temporal resolution due to the intensive labor and time required to analyze pollen. Samples represented broad spatial areas because microscopic charcoal can travel hundreds of kilometers (Clark, 1988; Conedera and Tinner, 2010). Variations in both pollen and charcoal abundances can influence the ratios, however, and so changes in pollen productivity could produce apparent changes in fire activity when none occurred. The differential production of charcoal from grass versus wood species could also alter charcoal/ pollen ratios. Thus, early reconstructions based on microscopic charcoalto-pollen ratios provided new and often useful insights, but the information was relatively coarse and potentially unreliable for inferring past regional fire activity.

Currently, most paleofire researchers analyze macroscopic charcoal particles $(>100 \mu \mathrm{m})$ sampled contiguously from sediment cores to produce fire-history records that are more spatially and temporally precise (e.g., "local" histories at decadal timescales) compared to earlier methods. Macroscopic charcoal is typically quantified by simple particle counts or area measurements made using image analysis (Carcaillet et al., 2001b). However, particles can also be characterized using morphotypes. Two primary particle forms for non-arboreal charcoal exist: (1) cellular "graminoid" (thin rectangular pieces; one cell layer thick with pores and visible vessels and cell wall separations) and (2) fibrous (collections or bundles of this filamentous charcoal clumped together). Arboreal charcoal can be characterized by three morphotypes: (1) dark (opaque, thick, solid, geometric in shape, some luster, and straight edges), (2) lattice (crosshatched forming rectangular ladder-like structure with spaces between), and (3) branched (dendroidal, generally cylindrical with successively smaller jutting arms; Jensen et al., 2007; Tweiten et al., 2009). 
The analysis of high-resolution macroscopic charcoal records focuses on decomposing temporal variations in particle measurements into low- and high-frequency signals. The low-frequency signals were originally termed "background" (Clark and Patterson, 1997) and were thought to primarily reflect non-fire processes within and around a site unrelated to fire occurrence, largely due to sediment redeposition. The background component was therefore explicitly filtered out and disregarded in analyses. Subsequent research, however, demonstrated that background charcoal contains important information about the relative amount of biomass burned through time (Haberle and Ledru, 2001; Carcaillet et al., 2002), particularly when combined across multiple records (Clark and Royall, 1996; Carcaillet et al., 2002; Marlon et al., 2006). Thus, the collection of many records into a single repository, including those of insufficient resolution for local fire-history reconstructions, became an important prerequisite for reconstructing variations in biomass burning at regional to global spatial scales.

Recent studies demonstrate that background charcoal corresponds well with independent evidence of area and/or biomass burned both at landscape scales (Higuera et al., 2011; Kelly et al., 2013) and regionally (Marlon et al., 2012). However, it is not possible to quantify absolute area burned in the absence of a calibration data set, and the influences of non-fire-related processes such as erosion or vegetation change on biomass burning reconstructions remain poorly understood (Aleman et al., 2013). These limitations highlight a need for more calibration studies to understand how charcoal production and taphonomy relates to the area and amount of biomass burned across a range of vegetation types and climate conditions.

Another recent advance in fire research is the reconstruction of fire frequency based on peaks in sedimentary charcoal records. Fire frequency is an important component of the fire regime, but such analyses require data sets with decadal resolution that are relatively uncommon in the GCD. In order to reconstruct fire frequency, records must be sampled contiguously, have high temporal resolution relative to the expected mean fire return intervals, and have sufficient particle counts in each sample to separate peaks from "background" (Higuera et al., 2007, 2010). In addition, relatively stable sediment accumulation rates are ideal because peak frequencies will vary with changes in sedimentation rates (Carcaillet et al., 2001a; Higuera et al., 2010). For these reasons, our analyses of the GCDv3, which are focused on broad-scale changes in fire, are limited to the reconstruction of fire activity or biomass burning rather than to changes in fire frequencies.

Many other methodological approaches to long-term firehistory reconstruction are developing from a variety of combustion products in ice cores (Kehrwald et al., 2013), including the analysis of ammonium $\left(\mathrm{NH}_{4}^{+}\right.$; Savarino and Legrand, 1998), methane (Fischer et al., 2008), carbon monoxide (CO; Wang et al., 2010), black carbon (Han et al., 2012; Lehndorff et al., 2015), vanillic acid (McConnell et al., 2007), and lev- oglucosan (Zennaro et al., 2014), as indicators of past fire activity. Laboratory and analytical methods are also advancing through the use of image analysis for counting charcoal and charcoal morphotypes (Enache and Cumming, 2006; Jensen et al., 2007; Thevenon and Anselmetti, 2007; Gu et al., 2008; Moos and Cumming, 2012).

Overall, the wealth of methods and approaches to fire research are providing a broad range of insights into fire, both as an ecological process and as an integrated component of the Earth system. However, much work remains to understand the impact of wildfires and biomass burning emissions on climate, and vice versa (Keywood et al., 2013). Research on human-fire interactions using paleorecords is developing rapidly (Colombaroli et al., 2008; Perry et al., 2012; McLauchlan et al., 2014; Munoz et al., 2014), but applying insights from paleofire research to fire management and emissions reduction plans remains comparatively limited (Whitlock et al., 2003; Cyr et al., 2009; Coughlan and Petty, 2012; Munoz et al., 2014). By compiling diverse types of paleofire data in a central location and developing opensource analysis tools to explore those data, research can advance more quickly on these topics.

\section{The Global Charcoal Database (version 3)}

The structure and contents of earlier versions of the GCD are outlined in Power et al. (2010). Here we review the database design and focus primarily on detailing new entries in GCDv3. Version 3 extends the total number of sites in the GCD to 736. It includes 679 sites from version 2 (Daniau et al., 2012) as well as new sites from recent regional syntheses from Australasia (Mooney et al., 2011), the Americas (Marlon et al., 2009, 2012; Power et al., 2012), and Europe (Vanniere et al., 2011).

\subsection{Geographical distribution}

Sites in GCDv3 come from five continents and exhibit a wide variety of temporal resolutions (Fig. 1). Most of the sites (436) are located in the Northern Hemisphere, which is due partly to its larger land area and partly to sampling bias; 300 sites come from the Southern Hemisphere. About $20 \%$ of southern hemispheric sites (178) are located in the tropics; most are located in forested regions, although sites increasingly come from grasslands, shrublands, and woodlands as well. The geographical distribution of the data reflects locations where fire research has traditionally focused and the presence of suitable locations for paleoenvironmental indicators. Sites are distributed between elevations of -9 to $4060 \mathrm{~m}$ a.s.l., with more than half (58\%) below $500 \mathrm{~m}$ a.s.l.; some records come from marine cores. Previous analyses of the distribution of GCD sites in climate space showed that the data set has relatively broad coverage with respect to global biomes and climate gradients (Daniau et al., 2012). Many 


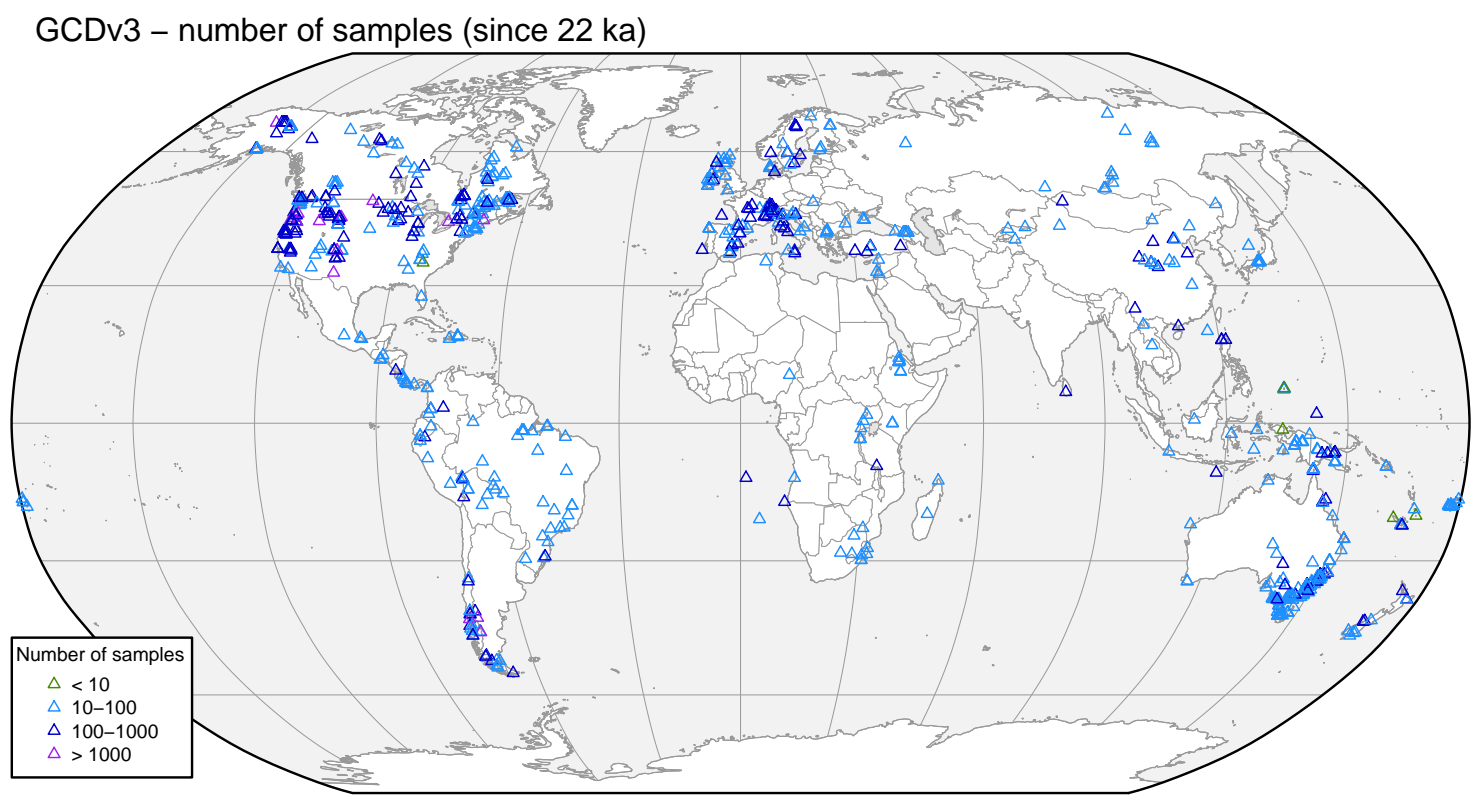

Figure 1. Location of paleofire sites and sampling density in the GCDv3.

newly published fire-history records exist that can potentially be incorporated into subsequent versions of the GCD (Brown, 2005; Han et al., 2012; Harley et al., 2012; Iglesias et al., 2012; Daniau et al., 2013; Kelly et al., 2013; QuintanaKrupinski et al., 2013; Tan and Huang, 2013; Cordeiro et al., 2014; Courtney Mustaphi and Pisaric, 2014; Dunnette et al., 2014; Higuera et al., 2014; Iglesias and Whitlock, 2014; Neumann et al., 2014; Walsh et al., 2015) and many more are in development that will fill important spatial gaps where fire is key, including Africa and the tropics.

\subsection{Type of records, data entry, and database structure}

The majority of sites in the database are associated with a single record in which charcoal was quantified using a single method. However, 96 sites in GCDv3 have more than one charcoal record, typically because charcoal was quantified using multiple metrics or laboratory techniques.

The charcoal data and metadata from the GCDv3 are stored in several formats. The primary complete data set is stored in a Microsoft Access relational database with four main and 23 supporting tables. The four main tables hold (1) site metadata such as site name and type, geographical coordinates, elevation, catchment size, data source, and dating type; (2) sample data, including depths, volume, and estimated ages; (3) charcoal data, including quantity, units, and quantification method; and (4) date information, including depth and type of dates, laboratory identification numbers, material dated, and associated errors. Additional tables include information such as the contact (i.e., the corresponding data contributor) and publications associated with each record, index tables (e.g., linking sites to publications and contacts), and full descriptions of codes used in the main tables. The original database was not designed to be a longterm archival repository but rather a research database, and it is therefore currently being replaced with a new structure. A significant percentage of the site metadata, such as geographic characteristics and methodological details, remains undocumented, however, and requires completion if scientific questions that draw on such data are to be addressed.

In addition to the database format, the GCDv3 data set is now available as part of the paleofire $\mathrm{R}$ package (Blarquez et al., 2014) for use with the $\mathrm{R}$ computer programming environment ( $R$ Development Core Team, 2013). The $\mathrm{R}$ package currently lacks some of the metadata that are contained in the full database, but the site metadata, charcoal data, and modeled ages are available. The complete GCD in the form of a relational database can be downloaded from paleofire.org and from the National Oceanic and Atmospheric Administration's (NOAA) National Centers for Environmental Information (NCEI; Power et al., 2008) website (http://www.ncdc.noaa.gov/paleo/impd/gcd.html).

Records in the GCD come from diverse environments (Tables 1,2$)$. Most of the sites in the database $(n=390)$ are lacustrine, which are primarily natural lakes that are often of glacial origin, but may also be of tectonic, volcanic, or thermokarst origin. Other records $(n=197)$ are from terrestrial environments, such as bogs, marshes, mires, and fens. A smaller number of records were obtained from soils $(n=52)$ and from coastal/fluvial $(n=35)$ or marine environments $(n=12)$. Depending on the objective of a particular study, some site types will be more suitable than others. Marine records, for example, are among the longest in the database, making them suitable for analyses of biomass burning during 
Table 1. Total number of sites by sediment and measurement type. The sediment types are lacustrine (LACU), bog (BOGM), unknown (NOTK), soil (SOIL), coastal (COAS), and marine (MARI). The measurement types stored in the database are concentration (CONC), influx, (INFL), proportions (COP0; e.g., ratio of charcoal particles to pollen grains), and other (OTHE).

\begin{tabular}{lrrrrrr}
\hline & LACU & BOGM & NOTK & SOIL & COAS & MARI \\
\hline CONC & 178 & 120 & 33 & 43 & 22 & 8 \\
INFL & 157 & 37 & 9 & 3 & 4 & 2 \\
COP0 & 45 & 37 & 8 & 4 & 9 & 2 \\
OTHE & 10 & 3 & 2 & 2 & 0 & 0 \\
Total & 390 & 197 & 52 & 52 & 35 & 12 \\
\hline
\end{tabular}

Table 2. Total number of sites by sediment type and catchment size. The sediment types are lacustrine (LACU), bog (BOGM), unknown (NOTK), soil (SOIL), coastal (COAS), and marine (MARI). Catchment sizes are small (SMAL; $<10 \mathrm{~km}^{2}$ ), medium (MEDI; $>10.1$ and $<500 \mathrm{~km}^{2}$ ), large $\left(\mathrm{LARG} ;>500 \mathrm{~km}^{2}\right)$, and unknown (NOTK).

\begin{tabular}{lrrrrrr}
\hline & LACU & BOGM & NOTK & SOIL & COAS & MARI \\
\hline SMAL & 194 & 100 & 4 & 13 & 15 & 0 \\
MEDI & 33 & 22 & 2 & 9 & 7 & 0 \\
LARG & 14 & 2 & 7 & 1 & 0 & 12 \\
NOTK & 149 & 73 & 39 & 29 & 13 & 0 \\
Total & 390 & 197 & 52 & 52 & 35 & 12 \\
\hline
\end{tabular}

the last glacial cycle (Daniau et al., 2010). However, marine sites have large catchment areas, making them suitable for regional but unsuitable for fine-scale analyses of fire activity.

\subsection{Charcoal quantification methods}

Important differences exist in the types of quantification methods within the database. Taken together, the 736 sites in GCDv3 have 134269 charcoal samples with estimated ages. For most of the sites, charcoal is quantified as concentration $(n=402)$ or influx $(n=212) ; 105$ are expressed in terms of charcoal to pollen ratios or similar measures of relative abundance; and the remaining 17 sites have uncommon units, such as cumulative probabilities or presence/absence of charcoal. Influx is the preferred unit of measurement for most biomass burning reconstructions because it accounts for variations in sedimentation rates over time, which can vary widely. If concentrations, depths, and ages exist, then influx can be calculated prior to analyses. Charcoal-to-pollen ratios, which were common in early analyses, are now relatively rare due to the ambiguities inherent in their interpretation (Conedera et al., 2009).

Different laboratory methods are used to quantify charcoal (Table 3). The majority of charcoal records included in the database (436 sites) are quantified using the pollen-slide method (POLS); 271 sites by sieving method (SIEV); 14 sites using image analysis (IMAG); and 15 sites were quantified using other methods such as hand picking charcoal from soil samples, gravimetric chemical assay (Winkler, 1985), and charcoal separation by heavy liquid preparation. Several records included were based on the cumulative probability of charcoal in alluvial fan deposits (Pierce et al., 2004), and several records employed other chemical, thermal, or optical treatments or some combination of these methods to quantify black or elemental carbon (Verardo et al., 1990).

\subsection{Chronology}

Accurate chronological dating of sediments is essential to paleo research. The quantity and quality of dating controls in GCDv3 records vary widely (Fig. 2). Some records have numerous, high-precision AMS radiocarbon dates, while others have few dates and poorly constrained chronologies with high or unknown uncertainties. Five common types of dates exist in the GCD, including AMS ${ }^{14} \mathrm{C}$, conventional ${ }^{14} \mathrm{C}$, ${ }^{210} \mathrm{~Pb}$, pollen-based correlations, and stratigraphy markers (e.g., tephras). Methods used to develop long-record stratigraphies are based on ${ }^{234} \mathrm{U} /{ }^{230} \mathrm{Th}$ ratios or orbital tie points. There are no major spatial patterns in the type of dating methods used, aside from the terrestrial/marine distinction, and the use of tephras in areas with volcanic activity (e.g., western coasts of the Americas). Differences in tephra dates among several records in the Pacific Northwest that use an ash layer associated with the eruption of Mount Mazama around 7700 years before present (yr BP, where present is 1950 CE) (Bacon, 1983) as a date in their age-depth models appear to need revision, as the eruption date was subsequently dated in multiple studies to $7627 \pm 150 \mathrm{cal} \mathrm{yr} \mathrm{BP}$ (Hallett et al., 1997; Zdanowicz et al., 1999). In general, radiocarbon dates (AMS or conventional) are the most common dating method reported in the GCD. The ${ }^{210} \mathrm{~Pb}$ dating is used for dating uppermost sediments (i.e., spanning the 
Table 3. Total number of sites by quantification type and laboratory analysis method.

\begin{tabular}{lrrrr}
\hline & $\begin{array}{r}\text { Proportion } \\
(\mathrm{COP} 0)\end{array}$ & $\begin{array}{r}\text { Concentration } \\
(\mathrm{CONC})\end{array}$ & $\begin{array}{r}\text { Influx } \\
(\text { INFL) }\end{array}$ & $\begin{array}{r}\text { Soil } \\
\text { (SOIL) }\end{array}$ \\
\hline Soil charcoal (CPRO) & 0 & 0 & 0 & 1 \\
Gravimetric (GRAV) & 1 & 1 & 0 & 0 \\
Hand picked (HNPK) & 0 & 7 & 0 & 0 \\
Heavy liquid preparation (HVLQ) & 0 & 4 & 0 & 0 \\
Imaging analysis (IMAG) & 0 & 12 & 2 & 0 \\
Oxidation resistant elemental & 0 & 1 & 0 & 0 \\
Carbon OREC \% of dry weight (OREC) & & & & \\
Pollen slide (POLS) & 81 & 259 & 98 & 0 \\
Sieved (SIEV) & 4 & 151 & 118 & 0 \\
Total & 86 & 435 & 218 & 1 \\
\hline
\end{tabular}

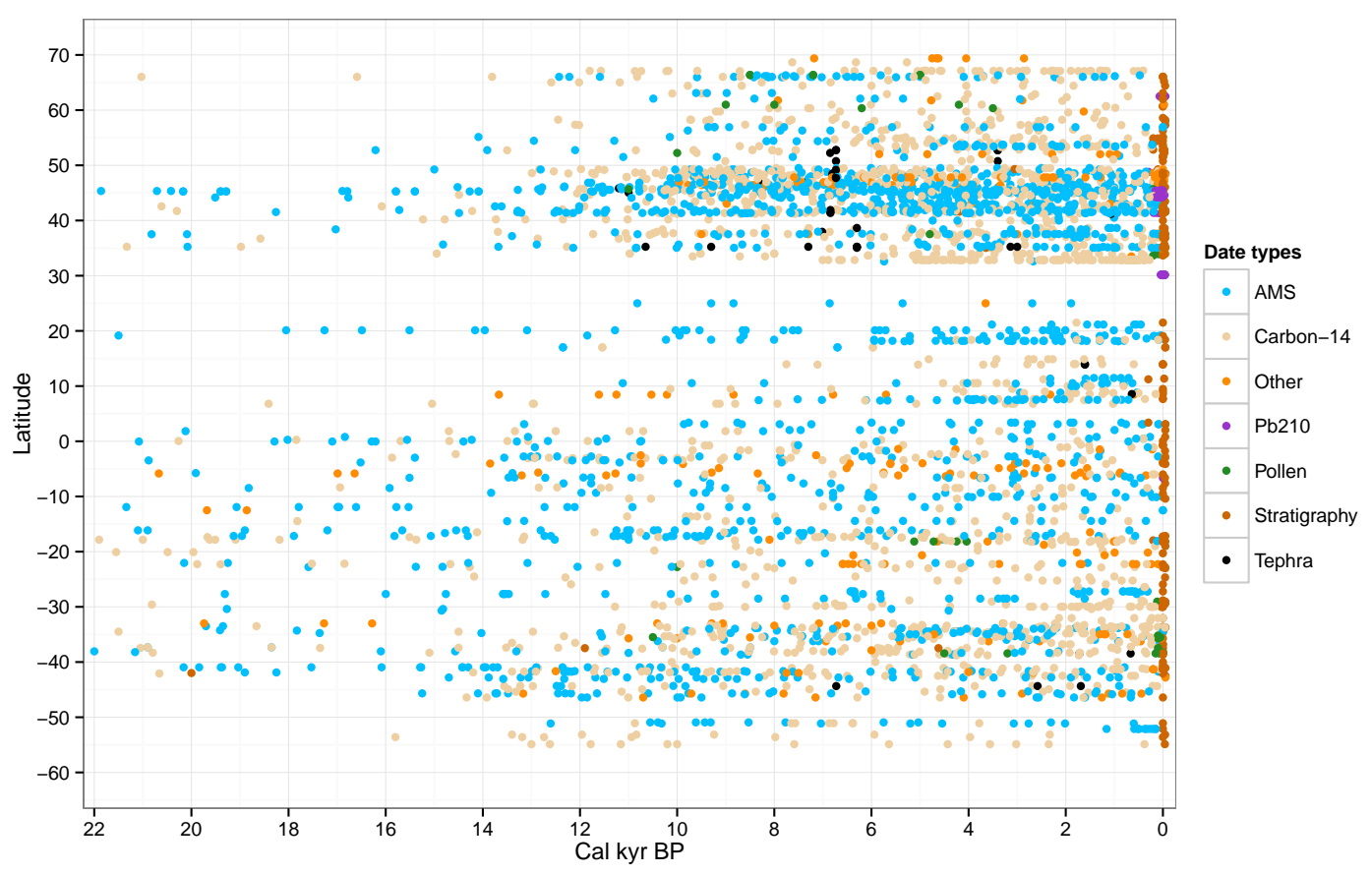

Figure 2. Temporal and latitudinal distribution of dates used to develop chronologies for records in the GCDv3 over the past 22000 years.

past 150 years) because ${ }^{210} \mathrm{~Pb}$ has the shortest half-life of the radioisotopes. When the sediment-water interface is retrieved during coring and is undisturbed, that core top sample is typically assigned the year in which the core was obtained; this sample is marked as "stratigraphic" in the legend of Fig. 2 and accounts for the stack of orange-colored dots around 0 cal yr BP (i.e., $1950 \mathrm{CE}$ ).

\section{Charcoal data standardization and compositing}

\subsection{From raw data to standardized accumulation rates}

Charcoal measurements can be obtained in a variety of ways, but the most common techniques employ particle counts, area measurements, or relative abundances (Power et al., 2010). The effects of local site characteristics such as lake size, watershed topography, and vegetation type on absolute charcoal influx values (Marlon et al., 2006), along with the diversity of quantification methods in common use (Conedera et al., 2009), results in values that vary over 13 orders of magnitude (Power et al., 2010), making it impossible at this time to directly compare metrics of biomass burned among sites. Charcoal records therefore must be standardized in order to examine relative changes in charcoal influx over time (Power et al., 2010). Once standardized, charcoal influx anomalies can be averaged from multiple records, even if the records are based on different methods, creating a composite series in which maxima, minima, trends, and other features can be identified and interpreted. 

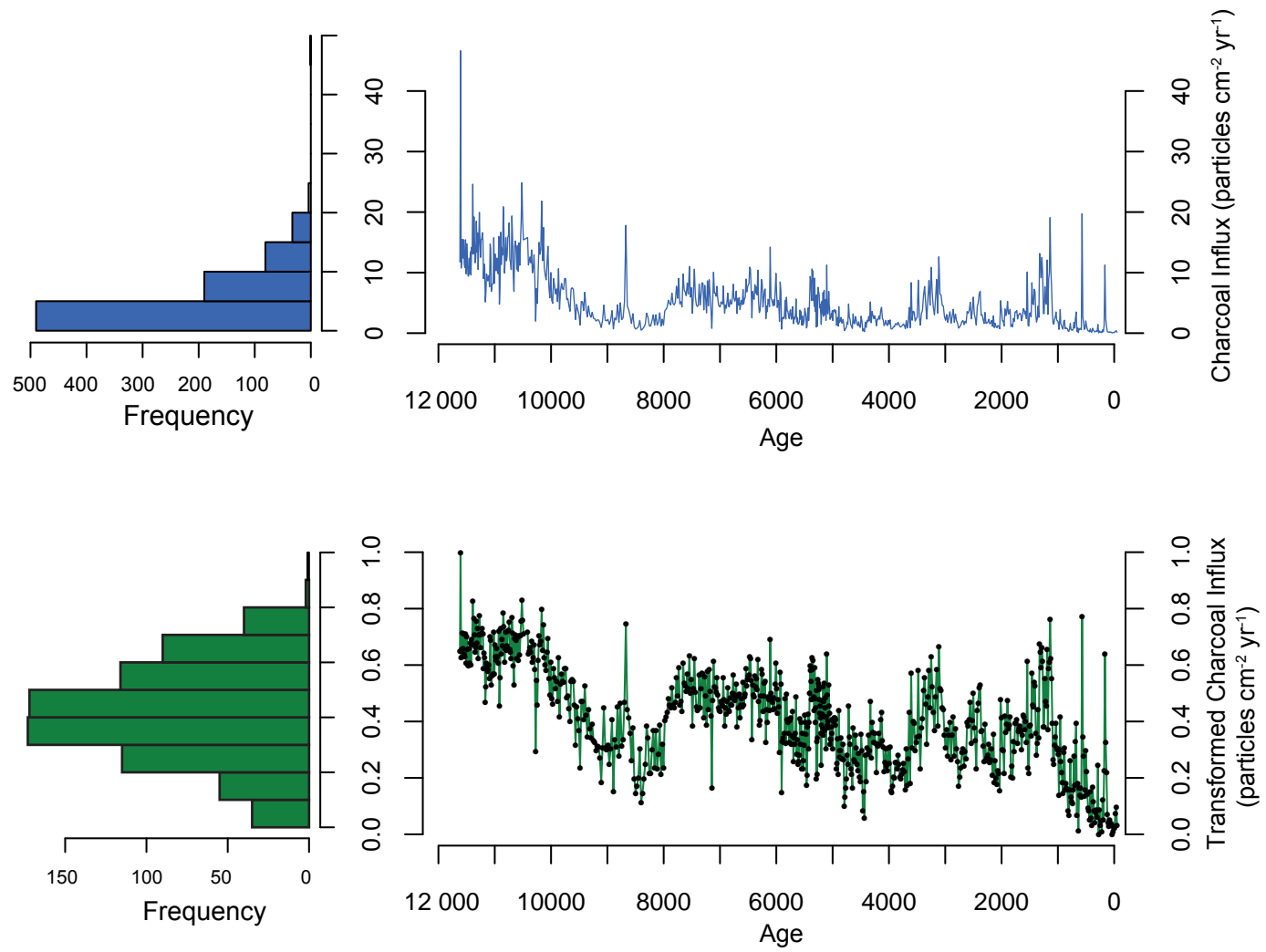

Figure 3. Example of untransformed and transformed charcoal influx (using the Box-Cox transformation) from Lago de Acessa, Tuscany, Italy (Vanniere et al., 2008). Number of particles per influx class is shown (left panels).

The charcoal syntheses presented here were standardized using a protocol (Marlon et al., 2008; Power et al., 2010) that includes (1) transforming non-influx values (e.g., concentration expressed as particles $\mathrm{cm}^{-3}$ ) to influx values (e.g., particles $\mathrm{cm}^{-2} \mathrm{yr}^{-1}$ ) by dividing the concentration values by sample deposition times $\left(\mathrm{yr} \mathrm{cm}^{-1}\right)$, (2) homogenizing the variance using the Box-Cox transformation, (3) rescaling the values using a minimax transformation to allow comparisons among sites, and (4) rescaling values once more to $z$ scores using a base period of 21000 to $200 \mathrm{yrs}$ BP. The base period ends at $200 \mathrm{yrs}$ BP because of the large human impacts on ignitions and suppression during the 19th and 20th centuries, which if included would obscure variability in charcoal accumulation rates prior to this period. However, the transformed records do extend into the 20th century $(-50 \mathrm{yr} \mathrm{BP}$, where CE $1950=0 \mathrm{BP})$. The most important step of the transformation is the homogenization of the variance (Fig. 3), which serves to make small-scale variations visible while also reducing the importance of high-value outliers.

\subsection{Compositing multiple standardized time series}

The purpose of compositing multiple charcoal records is to identify shared features and trends in fire history that may exist in a given spatial or temporal domain (e.g., North America during the Holocene). Given that individual charcoal time series are typically highly variable, averaging multiple records can provide insights into changes in fire history that only manifest at broad spatial scales (e.g., the impact of a changing climate within a given region). The variability in a record comes from a variety of factors, including the stochastic nature of lightning-caused fires (Bartlein et al., 2008), sitespecific factors such as topography, soils, and local vegetation that influence fire history, the complexities of charcoal production, transportation, and deposition, sediment sampling, and processing methods (Gavin et al., 2006). As a result, composite curves that are based on few records also tend to show relatively high variability (Fig. 4, top panel). As more records are included in the composite curve, the curve becomes smoother and the confidence intervals around the mean narrow (Fig. 4, middle and bottom panels), because averaging among many sites necessarily reduces peaks and other variations evident in individual sites.

Although charcoal records are typically composited to examine trends in fire history in a given geographic domain, composites can also be used to explore additional research questions. For example, combining all available records in the GCD from islands might yield insights into patterns of fire use associated with human colonization (McWethy et al., 2013). Alternatively, contrasting fire history from lakes 


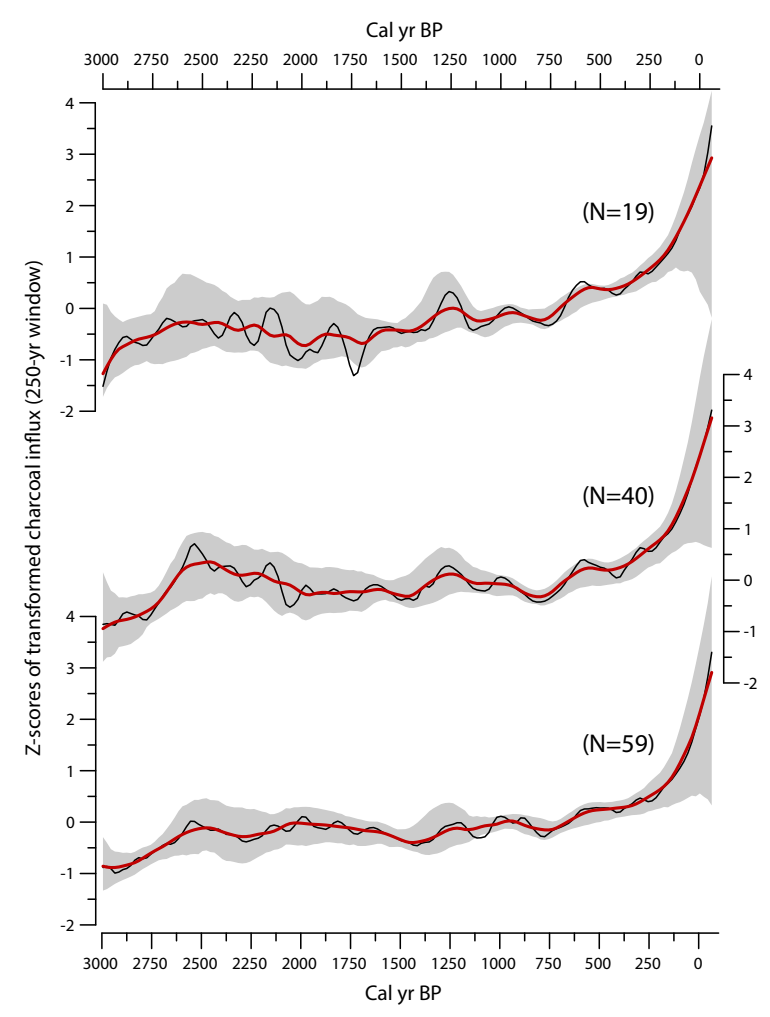

Figure 4. Three 3000-year biomass burning curves from eastern North America based on sites from an increasing number of adjacent grid cells show how the reconstructions become smoother and confidence intervals narrow as the number of sites and the spatial area included expand. Biomass burning reconstruction based on two adjacent grid cells containing a total of 19 records (top panel); three adjacent grid cells containing 40 records (middle panel), including the 19 from the top panel; and four adjacent grid cells representing a total of 59 records (bottom panel), including all previous. In all panels, red lines are based on 400-year smoothing windows, black lines based on 200-year windows, and bootstrap $95 \%$ confidence intervals from resampling by site are shown as gray bands.

versus peat bogs or marine records might yield insights into methodological questions about charcoal transportation and deposition. Compositing all records available during a particular time period may also offer insights into globally influential events like potential comet impacts (or lack thereof) (Marlon et al., 2009), volcanic events (Marlon et al., 2012), or into the effects of abrupt climate changes on fire (Daniau et al., 2010).

Irrespective of the research question, the process for compositing records is the same in each case. Each record is standardized as described above, but only after it is resampled to a common temporal resolution ("presampled") in order to standardize the influence of each record on the final composite curve. Presampling can be done using simple binning techniques, but a preferred method is to fit a loess curve to the series at regularly spaced target points (e.g., at 20-year intervals); the latter smooths over uncertainties in the sediment data as well as in the age model, whereas binning creates artificial cutoff points between samples that are in reality uncertain. After presampling, the records are standardized using a common base period, and a loess curve is again fitted to the pooled, transformed data using a fixed window width (e.g., 1000 years to generate a record of nominally "millennialscale" variability). Composite curves in this paper were produced following these methods as implemented in the R paleofire package (Blarquez et al., 2014).

Two issues that are not addressed by the above standardization and compositing approach relate to age uncertainties and spatial representativeness. While compositing many records can highlight regional trends in biomass burning, the different temporal uncertainty in individual records can make it difficult to accurately determine the precise timing of changes or to explore questions about synchroneity, for example. The number of radiocarbon dates or other chronological constraints in a record provide information about age uncertainties, and these dates are available in the GCD. However, formally assessing every age-depth model for the records in the GCD is a non-trivial task and should ideally be undertaken with the researchers who produced each record. Smoothing and gridding data accounts for age uncertainty in the records informally because the process only reveals trends and shifts in biomass burning that are robust across multiple records. More detailed analysis will always be needed, however, to address research questions about the sequence of particular changes or the precise timing of specific events. Similarly, the varying spatial representativeness of individual records are not accounted for in the compositing method described here. The myriad factors that affect charcoal production, transportation, and deposition in sediments means that there is no universal relationship between charcoal quantities and area burned that can be applied to all records. The conversion of all units to $z$ scores therefore allows the detection of trends in biomass burning over time but removes any information that may exist about the specific magnitude of area burned recorded by different records that make up a composite curve.

\section{The gridded charcoal data set}

To efficiently visualize GCDv3 and facilitate comparisons with model output, we present a spatially gridded version of GCDv3 using dot maps (Figs. 5, 6) alongside composite time-series curves (Figs. 5, 6). Vertical gray bars on the composite graphs indicate the time periods reflected in the maps. Each dot on the map represents a composite charcoal series constructed from all records within a fixed distance of the dot, such that the area represented by each dot is the same. However, the dots are positioned on a regular latitude/longitude grid, and the area of each grid cell varies by latitude (i.e., cells near the Equator cover larger areas than those near the poles); spacing dots in this way maximizes 


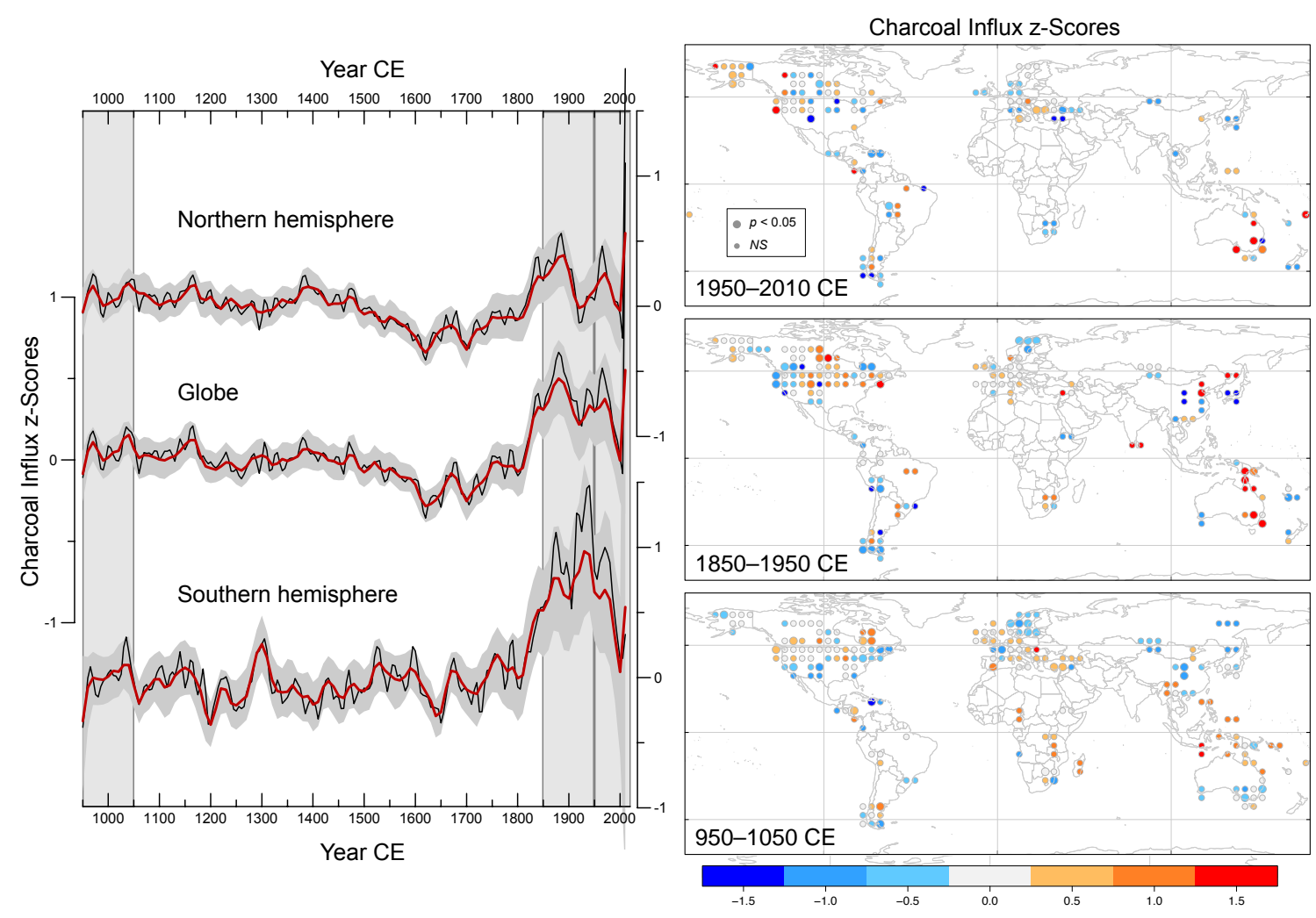

Figure 5. Trends in biomass burning (left panel) for the Northern Hemisphere, globe, and Southern Hemisphere for the past 1000 years and spatially gridded charcoal influx $z$ scores reflecting biomass burning (right panel) for the period 1950-2010, 1850-1950, and 950-1050 CE. Vertical gray bars through the time series on the left panel correspond to the time intervals shown in the gridded dot maps on the right panel. The charcoal influx anomaly base period for all panels is 1000-1800 CE. The smoothing window widths for the time series (left panel) are 40 years (red line) and 20 years (black line). Bootstrap-by-site confidence intervals (95\%) are filled in gray.

the compatibility of the gridded charcoal data set with other global data products. On such a grid, the absolute distance between dots (or nodes) decreases with distance from the Equator. We defined the radius used to identify sites contributing to a dot as half the distance between diagonally adjacent dots at the Equator (e.g., $\sim 395 \mathrm{~km}$ for a $5^{\circ} \times 5^{\circ}$ grid). This radius ensures that all GCD sites contribute to at least one dot but also causes sites to influence multiple dots, especially at high latitudes where dots are relatively close together in terms of absolute distance (Fig. 7). Finally, our gridding approach prevents interpolation into areas that are not represented in the GCD, which is desirable given the great spatial heterogeneity of fire regimes.

Anomaly maps illustrate the gridding approach at six discrete intervals during the past 1000 years (Fig. 5, left panel) and 22000 years (Figs. 6, left panel). Maps from each 100year period during the past millennium and each 1000-year interval since the Last Glacial Maximum (LGM) are provided in the Supplement. The charcoal values are plotted on a $5^{\circ}$ grid, and the dots are colored and sized to reflect the value and statistical significance, respectively, of the biomass burning anomalies (Fig. 5 and 6, right panels). The maps include data from three 100-year intervals (Fig. 5) and three 1000-year intervals (Fig. 6). Red dots on the maps indicate positive mean $z$ scores for sites in that location relative to their own long-term mean, which was calculated using a base period between 1000-200 years (Fig. 5) and 21000200 cal yr BP (Fig. 6). Blue dots on the map indicate negative mean $z$ scores. Because each dot shows changes in biomass burning relative to its own long-term average for that location, comparisons among dot colors on a single map (i.e., for a specific time) cannot be used to infer geographic patterns in biomass burning. For example, it is possible (or very likely, in fact) that for a given time period, a blue dot in Africa represents more biomass burning than a red dot in the Arctic. By contrast, changes in the color of a dot over time indicate meaningful temporal variability in the relative rate of biomass burning. A red dot in one time period that changes to a blue dot in the same location at another time period, for example, reflects an actual decrease in biomass burning over time at that location. One point of note is that it is possible in some cases for a recent time period to have less data than an older time period because samples from sediment cores are not regularly spaced in time, and core sections or tops are sometimes lost or destroyed in the field or during extraction. Most lake sediments provide continuous records, but soil and 

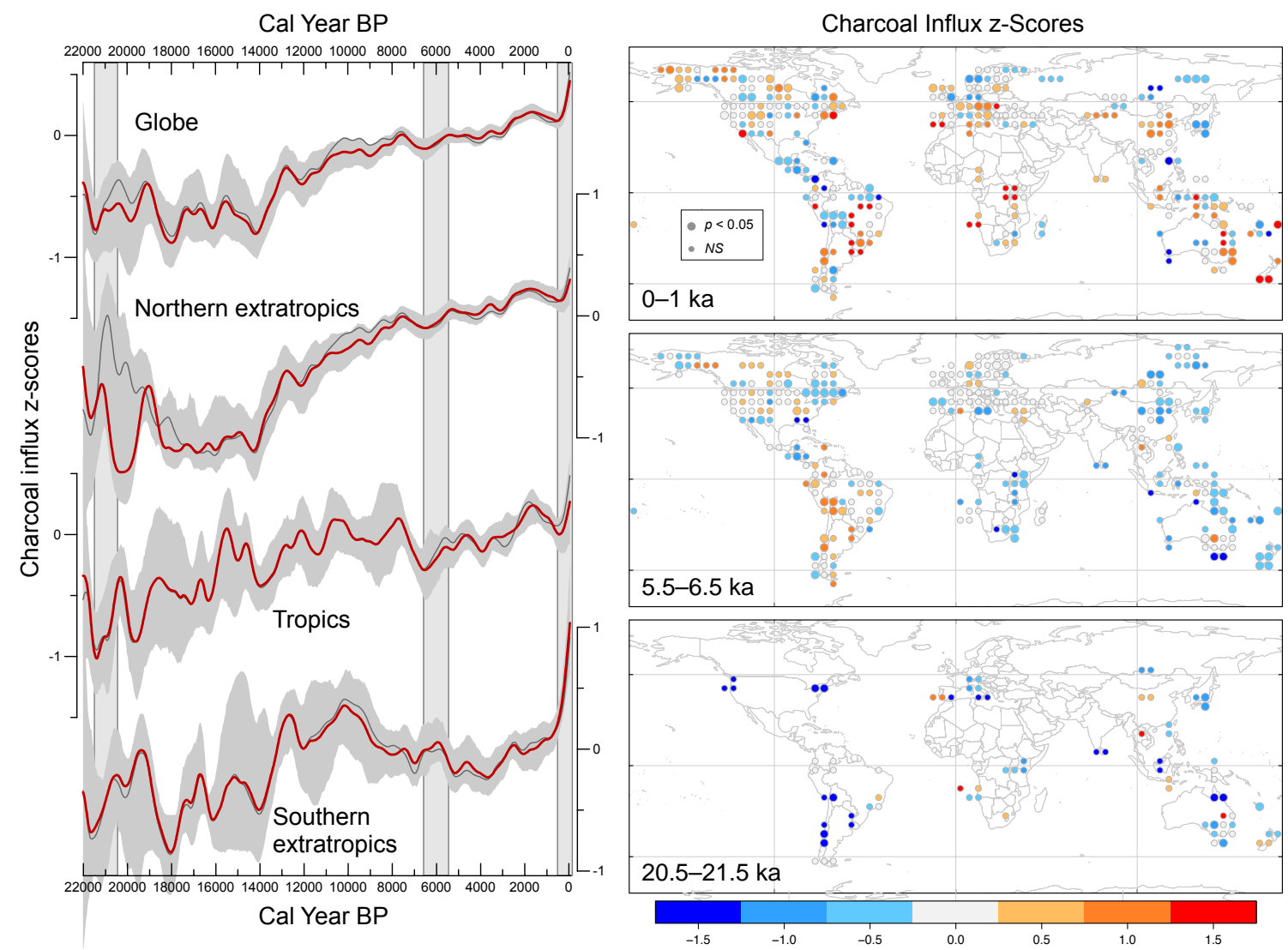

Figure 6. Trends in biomass burning (left panel) from 22 to $0 \mathrm{ka}$ from the GCDv3 (red) and GCDv2 (gray; Daniau et al., 2012) for the entire globe, northern extratropics ( $>30^{\circ} \mathrm{N}$ latitude), tropics $\left(>30^{\circ} \mathrm{N}\right.$ latitude and $<30^{\circ} \mathrm{S}$ latitude), and the southern extratropics $\left(<30^{\circ} \mathrm{S}\right.$ latitude), along with spatially gridded charcoal influx $z$ scores reflecting biomass burning (right panel) for the periods 0-1, 5.5-6.5, and 20.5-21.5 ka. Vertical gray bars on the left panel correspond to the intervals shown in the maps (right panel). The charcoal influx anomaly base period for all panels is $21 \mathrm{ka}-200 \mathrm{cal}$ yr BP; the smoothing window width is 1000 years. Bootstrap-by-site confidence intervals (95\%) are filled in gray.

bog profiles often have hiatuses when sites dry out or peat is burned, and occasionally this happens in lake and marine sediments as well. Another reason that a site may have less data closer to present than in the distant past is when sedimentation rates decline over time. In this case, a section of the core the represents the most recent past may only have one or two samples, whereas sections of the same size further down core may contain many samples.

A diagnostic map of the gridded charcoal data shows the effects of summarizing all data within a constant specified distance from each dot (Fig. 7). Effectively, the gridding approach allows each site to influence an equivalent spatial area on the map. However, it is helpful to keep in mind that given the same number of sites at high latitudes and at the Equator, the high-latitude sites will be more smoothed relative to those at the Equator, which is evident in the diagnostic maps from different time periods. Another effect of using equal-area circles to construct the dot maps is that a circle can be centered quite far from shore but still encompass a site on land. Thus dots may represent terrestrial sites despite being plotted in the ocean on our maps (although in some cases they repre- sent charcoal data actually collected from marine cores; see Figs. 1 and 7 for a comparison between location of sites and dots). Large (small) dots indicate biomass burning anomalies that are (not) significantly different from 0 .

Global biomass burning during the past millennium (Fig. 5) shows a gradual long-term decline until the 17th century during the Little Ice Age (LIA; Mann et al., 2009), as observed in previous reconstructions (Marlon et al., 2008). This decline is more pronounced in the Northern than Southern Hemisphere (Fig. 5, top and bottom panels). After the LIA, global biomass burning increases gradually until the 19th century, then rapidly until the 20th century. Maximum levels of biomass burning in the Northern Hemisphere occur prior to maximum levels in the Southern Hemisphere, and both hemispheres experience sharp declines in biomass burning during the second half of the 20th century. The maps of biomass burning show the spatial heterogeneity underlying the composite curves. Biomass burning in central and eastern North America is highest from 1850 to 1950 CE, for example, whereas burning in western North America is highest during the most recent period (1950-2010 CE). In contrast, 

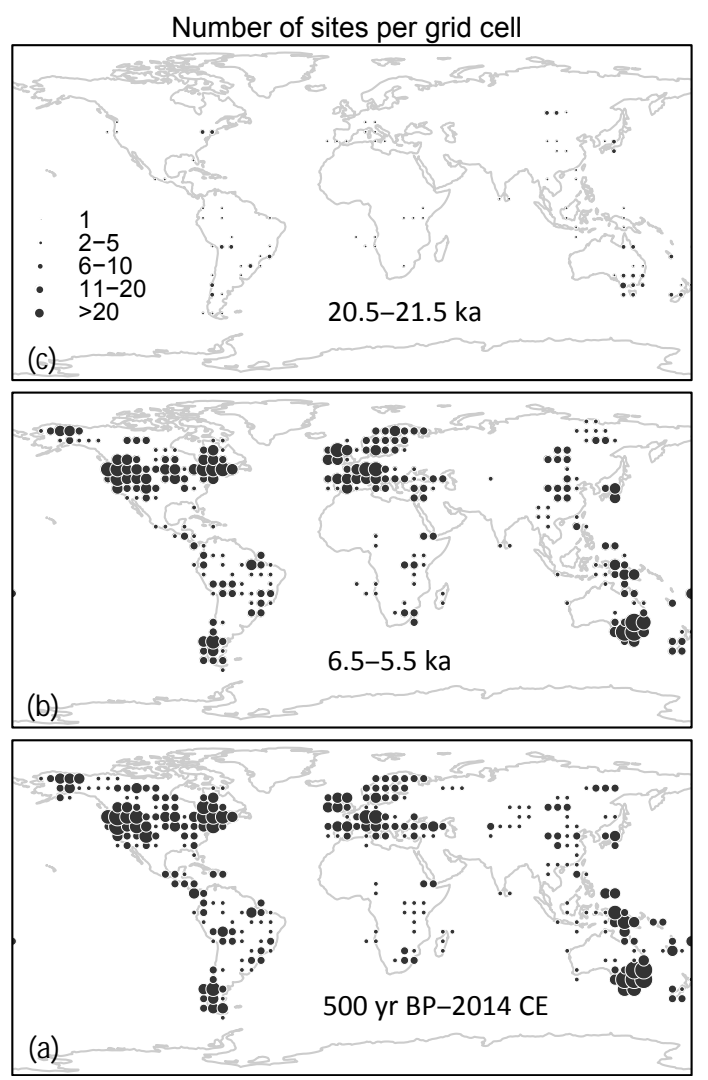

Figure 7. Diagnostic maps for the globally gridded data showing the number of sites per grid cell at (a) 0-1, (b) 5.5-6.5, and (c) 20.5$21.5 \mathrm{ka}$

burning in western and southern Europe is generally higher 1000 years ago than it is in the past two centuries. Burning in southeast Asia is very high from 1850 to $1950 \mathrm{CE}$ and remains high in several locations for the period 1950-2010 CE where data are available.

The most recent upturn in fire activity globally, but particularly in the Northern Hemisphere reconstruction, is supported by a larger data set than GCDv1. Marlon et al. (2008) used GCDv1 to document the large decrease in biomass burning in the 20th century, but the reconstruction had large uncertainties in the trend over the last few decades. The addition of new records to versions 2 and 3 of the GCD, along with a finer-scale temporal focus now reveals the most recent increases in fire activity observed not only in the charcoal data but also in several lines of independent evidence, including satellite and observational data (Giglio et al., 2013; Dennison et al., 2014).

Global biomass burning since the LGM, 21000 years ago, shows a long-term increase (Fig. 6) consistent with increasing temperatures, atmospheric $\mathrm{CO}_{2}$ concentrations, and burnable biomass (Daniau et al., 2012; Martin Calvo et al., 2014). The reconstructions from GCDv3 (red lines) are very similar to those from GCDv2 (thin gray lines) for the globe, northern extratropics $\left(>30^{\circ} \mathrm{N}\right.$ latitude), tropics $\left(>30^{\circ} \mathrm{N}\right.$ latitude and $<30^{\circ} \mathrm{S}$ latitude), and southern extratropics $\left(<30^{\circ} \mathrm{S}\right.$ latitude), with the exception of burning in the northern extratropics during the LGM, which registers as very low with the additional records in GCDv3 as compared with GCDv2 (Fig. 6). However, the Northern and Southern hemispheres show somewhat inverse patterns of burning during the Holocene, with fire increasing steadily in the northern extratropics during the Holocene, but declining in the early to mid-Holocene in the tropics and southern extratropics, before increasing in the late Holocene.

The gridded maps provide insight into the spatial variations in biomass burning since the LGM.

Burning is generally higher in the past millennium than at any time since the LGM with the exception of centralwestern South America (Fig. 6), where some locations had higher than average burning during the mid-Holocene and below average burning in the past millennium. Levels of burning during the LGM in turn were generally lower than at later periods, with a few localized exceptions. Particularly high levels of biomass burning in the past millennium are observed in many locations in the Southern Hemisphere (e.g., New Zealand, central Africa, the Amazon) as well as in parts of the Northern Hemisphere (e.g., northeastern North America, southern California, and the southern Iberian Peninsula). The maps also reveal spatial coherence in regional biomass burning since the LGM, which likely reflects climate controls on fire in some cases and human controls on fire in others - the degree of coherence alone cannot distinguish causal mechanisms at this scale.

\section{Using charcoal data in model validation}

The development of the GCD is motivated by the need to understand the history of fire on Earth and the linkages among fire, climate, vegetation, and human activities. As the GCD continues to expand, the expectation is that knowledge of fire histories will become more detailed. Analyzing charcoalbased fire-history records with modern data from satellites (e.g., van der Werf et al., 2010; Giglio et al., 2013), fire scars (e.g., Girardin and Sauchyn, 2008; Marlon et al., 2012), or historical records (e.g., Mouillot et al., 2006; Lamarque et al., 2010) is necessary to connect relative or qualitative variations in biomass burning from charcoal records (Aleman et al., 2013) to quantitative estimates of burned area or carbon emissions. To test hypotheses related to drivers of fire activity over longer timescales, however, research needs to integrate paleofire data with modeling approaches. As the spatial network of charcoal records become denser, there is increasing opportunity to identify locations where varying types of fire records overlap and thus more opportunities to study changes in fire regimes that span multiple spatial and temporal scales.

Fire modeling efforts have advanced rapidly in the last decade (Arora and Boer, 2005; Kloster et al., 2010; Kelley 
et al., 2014; Lasslop et al., 2014; Yue et al., 2014; Le Page et al., 2015), providing a better understanding of the varied impacts that fires have on humans, the biosphere, and the atmosphere (Harrison et al., 2010), as well as the mechanisms through which climate changes and human activities affect fire regimes. Simulations of fire activity using physically based empirical relationships between flammability and its controlling variables, such as temperature and soil moisture, have helped identify the global drivers of modern burning (Arora and Boer, 2005; Kloster et al., 2010; Pechony and Shindell, 2010; Thonicke et al., 2010; Li et al., 2013; Pfeiffer et al., 2013). Fire modeling studies have also qualitatively compared paleofire trends with simulated global fire activity (Pechony and Shindell, 2010; Kloster et al., 2012; Li et al., 2013), but quantitative testing of the physically based relationships that drive fire models - the mechanics of the models themselves - has only focused on modern climate conditions thus far. As a result, large gaps in knowledge exist about how fire, climate, vegetation, and humans interact under different climate conditions and over long timescales. Despite the fact that mechanistic global fire models remain largely untested outside modern climate parameters, these models are being used to predict the response of fires to ongoing climate change (Pechony and Shindell, 2010; Kloster et al., 2012).

The fire modeling studies that have explicitly considered paleofire data provide examples of the challenges in comparing data and models. A study by Pechony and Shindell (2010) tested a global fire model scheme within a Global Climate Model simulation of the past millennium, for example, and found that at coarse spatial scales precipitation was the most important factor driving multi-centennial variations in fire activity in the model. However, the spatial patterns underlying these trends, and the extent to which finer-scale variations match paleofire evidence are unknown. Moreover, the finding that precipitation is more important than temperature in driving trends in fire activity globally contradicts analyses of paleodata (Daniau et al., 2012; Marlon et al., 2012; Power et al., 2012; Marlon et al., 2013), as well as satellite remote-sensing data (Bistinas et al., 2013), raising key questions about how temperature, precipitation, and their interactions affect variations in global biomass burning. Another fire modeling study (Brücher et al., 2014) compared model output to paleofire data from the GCD at regional scales from the mid-Holocene until the pre-industrial era in the 18th century. Kloster et al. (2015) go one step further to test the sensitivity of the same model to variations in fuel availability, fuel moisture, and wind speed, as well as their synergy for the same regions and time period.

The new approach to gridding GCD data presented here (and included in the paleofire R package) should help further paleofire data-model comparison studies. Whereas modeling studies to date have focused on global or regional trends, the growing number of records in the GCD allows for evaluation of model performance at finer spatial scales. However, site-

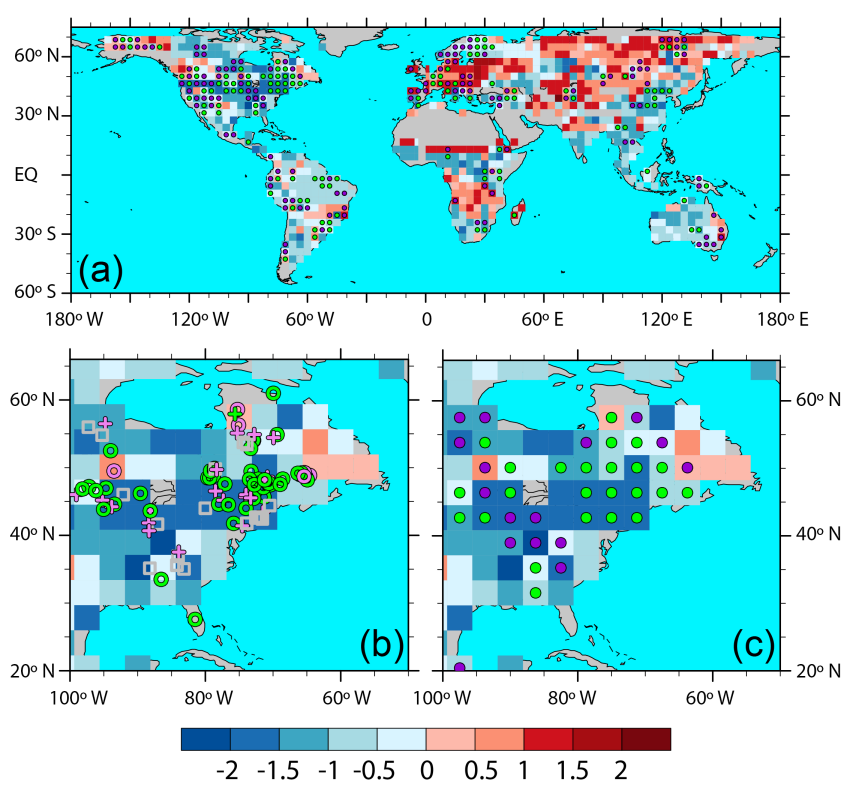

Figure 8. Modeled (filled grid boxes; Brücher et al., 2014) vs. reconstructed (GCDv3) fire activity at global (a) and regional (b, c) scales. Both data and model represent millennial anomalies at $6 \mathrm{ka}$ relative to present (i.e., mean $z$ scores for $5.5-6.5 \mathrm{ka}$ minus mean $z$ scores for 500 cal yr BP to present). In all panels, green and pink symbols indicate GCD data that agree or disagree (respectively) with model output in terms of the sign of the $6-0 \mathrm{ka}$ anomaly. In (a) and (c) the data are gridded following methods presented in Sect. 5. In (b), anomalies for individual GCD sites are plotted, with symbols indicating positive ("+") or negative ("o") anomalies; records that do not span the full $6 \mathrm{ka}$ interval are shown (gray squares) but excluded from the analysis.

specific variability is often high among charcoal records, and driver data sets for many global fire models may be of relatively coarse resolution. As a result it is ill-advised to compare model output to individual charcoal records. The gridded approach offers a flexible compromise that can be tuned in terms of spatial resolution depending on data availability, model driver data sets, and other factors. As an example, we present here a global map of simulated area burned using the CLIMBA model (Brücher et al., 2014), overlaid with gridded composite charcoal anomalies from the GCD. CLIMBA consists of the EMIC CLIMBER-2 (CLIMate and BiosphERe; Petoukhov et al., 2000; Ganopolski et al., 2001) and JSBACH (Raddatz et al., 2007; Brovkin et al., 2009; Reick et al., 2013; Schneck et al., 2013), which is the land component of the Max Planck Institute Earth System Model (MPI-ESM, Giorgetta et al., 2013). Simulated area burned throughout the Holocene was treated analogously to GCD data to produce a gridded map of area-burned anomalies at $6000 \mathrm{BP}$ relative to present (i.e., $6000 \mathrm{BP} z$ scores minus $0 \mathrm{BP} z$ scores).

Overall, data-model agreement is weak, with many grid cells disagreeing in terms of the sign of the anomaly estimated from the CLIMBA model versus GCD data (Fig. 8a). 
However, the exercise shows promise for some regions. In eastern North America, for example, site-level GCD data are difficult to reconcile with model output (Fig. 8b), but the gridded data product shows that both data and model generally agree that $6000 \mathrm{BP}$ was a period of lower fire activity than present for the region (Fig. 8c). It is beyond the scope of this paper to evaluate the importance of this agreement, or the causes of data-model mismatch in other regions throughout the globe. Instead, we present the example as a proof-ofconcept to motivate future studies. Important basic research topics to pursue include evaluation of spatiotemporal patterns in data-model comparisons, and a critical assessment of how uncertainties in both GCD data and fire model output contribute to the comparisons.

Using fire-history data from the GCD to constrain fire model simulations, or conversely, using fire model simulations to understand variability in the fire-history data from the GCD, requires careful consideration of the uncertainties associated with both data types. For paleofire records, quantifying and accounting for age uncertainties is a major concern, but progress is occurring on this front through the development of Bayesian age-modeling methods (Blaauw and Christen, 2011; Goring et al., 2012). Uncertainties in charcoal records also come from the many natural processes related to charcoal production, transportation, and deposition, which interact to produce variability in charcoal accumulation over time. These processes are being studied through field experiments and calibration studies that will enable the development of higher quality fire-history reconstructions and a better understanding of uncertainties (Tinner et al., 2006; Higuera et al., 2011; Aleman et al., 2013). An important source of uncertainty in global fire models is the parameterization of the processes most directly controlling fire activity (e.g., human influence, climate influence; e.g., Pechony and Shindell, 2009; Pfeiffer et al., 2013). The sensitivity of simulated fire activity to such parameterizations needs to be tested to understand model uncertainty. Uncertainty in modern fire records arises from any extrapolation or interpretation beyond the available fire records (Mouillot et al., 2006) or to limits in the satellite data itself (Giglio et al., 2013). With detailed considerations of both the limits and uncertainties of all data sources and model parameterizations, connecting GCD to fire models represents the natural evolution in the effort to understand fires in the Earth system.

\section{Future recommendations}

There are several research areas that, with further development, would facilitate rapid integration of fire data and a more comprehensive understanding of fire across spatiotemporal scales. Here we identify particular areas that would help address specific barriers to progress in paleofire research.
- Charcoal calibration studies in diverse environments. A major limitation of biomass burning reconstructions is that they can only represent relative changes in burning from an arbitrary baseline. Calibration studies that relate variability in charcoal accumulation to fire regime characteristics from historical, fire-scar, satellite, and other recent data could allow additional information to be obtained from charcoal records. Given the complexities of charcoal production, transportation and deposition, it is unlikely that the absolute amount of biomass burning from a single paleofire time series can be known; however, with a better understanding of how charcoal abundances relate quantitatively to area burned or other fire-regime metrics, constraints on paleofire reconstructions can be established and integrated into models that can then provide quantitative estimates of variables like area burned and carbon emissions.

- Multiproxy studies of paleofire history. Comparisons of paleofire data from multiple sources, such as charcoal, black carbon, and levoglucosan, are needed to better understand the roles of changes in area burned, fire frequency, fire type, and emissions in carbon cycling and the climate system. The combustion of vegetation produces a wide array of products, but many of these (e.g., ammonium and black carbon) are not specific to biomass combustion. As a result, developing methods for effectively comparing different types of data that imperfectly reflect fire emissions may improve our understanding of fire by providing convergent evidence for particular features, enhancing the temporal or spatial resolution of reconstructions, or refining our understanding of proxy source areas. By improving our ability to compare and integrate diverse sources of firehistory information, we can more clearly identify and potentially offset the weaknesses of each particular data type.

- Data-model comparisons of paleofire history. A primary motivation for the development of the GCD has been to create data sets for use in the development and validation of global fire models. Mechanistic and process-based simulations of fire activity at multiple spatiotemporal scales necessarily depend on an accurate understanding of the controls of biomass burning. The GCD can directly inform fire models on this point. Paleofire data-model comparisons are an emerging field in many respects. Spatiotemporal comparisons of GCD to fire model output will help move research forward into deeper analyses of how uncertainties associated with both the data and the models contribute to our collective understanding of paleofire history and implications for future model-based fire projections.

- Filling gaps in paleofire data. Data collection from regions that are presently underrepresented in the GCD 
(e.g., Africa, the tropics, tundra and heathlands, and the boreal forests of Eurasia) is essential for learning how fire varied in response to climate forcings and human activity in the past, particularly in unique vegetation types and in biodiversity hotspots. Understanding fire-climate-vegetation interactions can supplement our knowledge from data-poor areas, but given the contingencies and legacies that land-use practices have on land cover and disturbance regimes (McLauchlan et al., 2014), having data from specific geographic locations is often necessary.

- Comparisons between charcoal data and other spatially extensive data sets. The development of large environmental data sets during the past few decades has opened up a new frontier in global change science. New research into the interactions among climate, vegetation, human activities and fire during the Holocene and in the more distant past can now be supported by large simulated and observed paleoclimate data sets, pollen data sets, and data on population growth, land-use, and landcover change. Analyzing these data sets jointly with the GCD can provide insights into how changes in fire regimes affect rates of ecological change and biodiversity (Colombaroli et al., 2012), how fire affects species migration (Edwards et al., 2015), or whether humans altered the climate system using fire in the early Holocene (Marlon et al., 2013).

In addition to the research needs above, several practices could aid in the development of high quality charcoalbased fire-history reconstructions and facilitate data integration across labs and therefore across different environmental contexts. The practices may be more useful to new researchers entering the field or establishing new labs.

- Continuous sampling of macroscopic charcoal data. Although many researchers now sample lacustrine sediment continuously and quantify macroscopic charcoal, many continue to tally microscopic particles, or to sample discontinuously. Taking the latter approach may be necessary due to methodological, funding, or other constraints, but when it is possible, the former approach is more desirable. Research on charcoal particle size classes supports macroscopic particles $(>100 \mu \mathrm{m})$ as a reliable indicator of local (within 1-10+ kilometers of a study site) fire activity (Whitlock and Bartlein, 2004), whereas smaller particles integrate biomass burning from a larger spatial domain (Conedera et al., 2009). If both macroscopic and microscopic particles can be tallied, they may provide complimentary evidence of past fire regime change. However, if only one particle size is collected, analysis of macroscopic charcoal usually provides a better signal for local fire reconstruction. While continuous sampling is more time and cost intensive, it facilitates reconstructing event frequency, aligning mul- tiple cores, detecting unique events, and examining rates of change.

- Separating woody and herbaceous charcoal. In environments that may have had grasses as a fuel source, separate tallying of woody and herbaceous charcoal (e.g., Walsh et al., 2008) can be of great value (e.g., Daniau et al., 2013) in identifying temporal variability in fuel types. Additional charcoal morphotypes can be observed and classified as well (Enache and Cumming, 2006; Mustaphi and Pisaric, 2014), but the application of these methods remains largely untested. In the meantime, separate tallies only of woody and herbaceous charcoal have already been shown to provide reliable information about fuel sources (e.g., Wooller et al., 2000; Walsh et al., 2008; Maezumi et al., 2015) and are recommended when possible.

- Data sharing and open-source code. The importance of data sharing, and increasingly code sharing, is now widely recognized in the scientific community (Easterbrook, 2014). Sharing data and code facilitates and encourages reproducibility, allows comparative data analysis, and promotes scientific progress in general. Data sharing is also essential for addressing questions at broad spatial scales, evaluating alternative laboratory and analytical methods, and ensuring that limited research funds are used efficiently. Although sharing data and code introduces overhead costs for data management and archive maintenance, the benefits to individuals, the scientific community, and the public at large are increasingly recognized as far outweighing these costs. The research presented in this paper is just one example of the science that is possible with data and code sharing; we hope academic institutions, publishers, and funders continue to encourage and incentivize such practices (Kattge et al., 2014).

\section{Conclusions}

The GCDv3 incorporates 736 charcoal records and can now be gridded globally for the modeling community to ease future data-model comparisons. Fire-history reconstructions from the GCDv3 demonstrate that increases in biomass burning since the last glacial period were widespread, as are unusually high levels of burning over the past several decades. Present-day burning inferred from the charcoal data is particularly high in western North America and southeastern Australasia. Detailed reconstructions of temporal variations in biomass burning during the past 1000 years reveal that a global biomass burning decline from 1000 to the LIA was more pronounced in the Northern than Southern Hemisphere. In addition, variations in fire activity during the past 200 years show very different spatial patterns. In general, datamodel comparisons with paleofire data provide a powerful 
method for testing hypotheses about interactions between climate and fire outside the range of modern climate conditions. Results from such data-model comparisons will highlight gaps and weaknesses in both data and models, allowing targeted refinements to be identified and prioritized. We identify five areas of focus to promote future progress in paleofire research, including (1) charcoal calibration studies in diverse environments, (2) multiproxy studies of paleofire history, (3) paleofire data-model comparisons, (4) filling gaps in paleofire data, (5) comparisons between charcoal data and other large data sets, and (6) enhanced data extraction from existing cores, like continuous sampling and herbaceous charcoal identification.

\section{Data availability}

The complete GCDv1, v2, and v3 (this paper) Microsoft Access database with all available metadata is stored and available at paleofire.org. Supporting information about the Global Charcoal Database and the Global Palaeofire Working Group is also available at paleofire.org. Site metadata and the charcoal data are accessible through the paleofire package (Blarquez et al., 2014) for R (R Development Core Team, 2013).

\section{The Supplement related to this article is available online} at doi:10.5194/bg-13-3225-2016-supplement.

Acknowledgements. We thank PAGES working group support for the GPWG. This research and paper was initiated during the GPWG workshop 2013 held in Franche-Comté and supported by the UMR Chrono-Environnement, the OREAS project, the University of Franche-Comté, and the Région Franche-Comté. Jennifer R. Marlon is supported by NSF grants BCS-1437074 and EF-1241870. Patrick Bartlein and Brian Magi are supported by NSF grant BCS-1437074. Anne-Laure Daniau is supported by the project PICS CNRS 06484. Philip Higuera was supported by NSF grant IIA-0966472. Boris Vannière is supported by the project MISTRALS-PaleoMEX.

Edited by: A. Ito

\section{References}

Aleman, J. C., Blarquez, O., Bentaleb, I., Bonté, P., Brossier, B., Carcaillet, C., Gond, V., Gourlet-Fleury, S., Kpolita, A., Lefèvre, I., Oslisly, R., Power, M. J., Yongo, O., Bremond, L., and Favier, C.: Tracking land-cover changes with sedimentary charcoal in the Afrotropics, Holocene, 23, 1853-1862, 2013.

Arora, V. K. and Boer, G. J.: Fire as an interactive component of dynamic vegetation models, J. Geophys. Res., 110, 1-20, 2005.
Bacon, C. R.: Eruptive history of Mount Mazama and Crater Lake Caldera, Cascade Range, USA, J. Volcanol. Geoth. Res., 18, 57 117, 1983.

Bartlein, P., Hostetler, S. W., Shafer, S. L., Holman, J. O., and Solomon, A. M.: Temporal and spatial structure in a daily wildfire-start data set from the western United States (1986-96), Int. J. Wildland Fire, 17, 8-17, 2008.

Behling, H.: Late Quaternary environmental changes in the Lagoa da Curuça region (eastern Amazonia, Brazil) and evidence of Podocarpus in the Amazon lowland, Veg. Hist. Archaeobot., 10, 175-183, 2001.

Bistinas, I., Oom, D., Saì, A. C. L., Harrison, S. P., Prentice, I. C., and Pereira, J. M. C.: Relationships between human population density and burned area at continental and global scales, PLoS ONE, 8, e81188, doi:10.1371/journal.pone.0081188, 2013.

Blaauw, M. and Christen, J. A.: Flexible paleoclimate age-depth models using an autoregressive gamma process, Bayesian Analysis, 6, 457-474, 2011.

Blarquez, O., Vannière, B., Marlon, J. R., Daniau, A.-L., Power, M. J., Brewer, S., and Bartlein, P. J.: paleofire: An R package to analyse sedimentary charcoal records from the Global Charcoal Database to reconstruct past biomass burning, Comput. Geosci., 72, 255-261, 2014.

Bond, W. J. and Keeley, J. E.: Fire as a global 'herbivore': the ecology and evolution of flammable ecosystems, Trends Ecol. Evol., 20, 387-394, 2005.

Brovkin, V., Raddatz, T., Reick, C. H., Claussen, M., and Gayler, V.: Global biogeophysical interactions between forest and climate, Geophys. Res. Lett., 36, L07405, doi:10.1029/2009GL037543, 2009.

Brown, K. J., Clark, J. S., Grimm, E. C., Donovan, J. J., Mueller, P. G., Hansen, B. C. S., and Stefanova, I.: Fire cycles in North American interior grasslands and their relation to prairie drought, P. Natl. Acad. Sci. USA, 102, 8865-8871, 2005.

Brücher, T., Brovkin, V., Kloster, S., Marlon, J. R., and Power, M. J.: Comparing modelled fire dynamics with charcoal records for the Holocene, Clim. Past, 10, 811-824, doi:10.5194/cp-10-8112014, 2014.

Burney, D. A.: Late Quaternary stratigraphic charcoal records from Madagascar, Quaternary Res., 28, 274-280, 1987.

Carcaillet, C., Bergeron, Y., Richard, P. J. H., Fréchette, B., Gauthier, S., and Prairie, Y. T.: Change of fire frequency in the eastern Canadian boreal forests during the Holocene: does vegetation composition or climate trigger the fire regime?, J. Ecol., 89, 930946, 2001a.

Carcaillet, C., Bouvier, M., Fréchette, B., Larouche, A. C., and Richard, P. J. H.: Comparison of pollen-slide and sieving methods in lacustrine charcoal analyses for local and regional fire history, Holocene, 11, 467-476, $2001 \mathrm{~b}$.

Carcaillet, C., Almquist, H., Asnong, H., Bradshaw, R. H. W., Carrión, J. S., Gaillard, M. J., Gajewski, K., Haas, J. N., Haberle, S. G., Hadorn, P., Müller, S. D., Richard, P. J. H., Richoz, I., Rösch, M., Sánchez Goñi, M. F., Von Stedingk, H., Stevenson, A. C., Talon, B., Tardy, C., Tinner, W., Tryterud, E., Wick, L., and Willis, K. J.: Holocene biomass burning and global dynamics of the carbon cycle, Chemosphere, 49, 845-863, 2002.

Clark, J. S.: Particle motion and the theory of charcoal analysis: source area, transport, deposition, and sampling, Quaternary Res., 30, 67-80, 1988. 
Clark, J. S. and Royall, P. D.: Local and regional sediment charcoal evidence for fire regimes in presettlement north-eastern North America, J. Ecol., 84, 365-382, 1996.

Clark, J. S. and Patterson, W. A.: Background and local charcoal in sediments: scales of fire evidence in the paleorecord, in: Sediment records of biomass burning and global change, edited by: Clark, J. S., Cachier, H., Goldammer, J. G., and Stocks, B. J., Springer-Verlag, Berlin, 1997.

Colombaroli, D., Tinner, W., Leeuwen, J. v., Noti, R., Vescovi, E., Vanniere, B., Magny, M., Schmidt, R., and Bugmann, H.: Response of broadleaved evergreen Mediterranean forest vegetation to fire disturbance during the Holocene: insights from the periAdriatic region, J. Biogeogr., 36, 314-326, 2009.

Colombaroli, D., Vanniere, B., Emmanuel, C., Magny, M., and Tinner, W.: Fire-vegetation interactions during the MesolithicNeolithic transition at Lago dell'Accesa, Tuscany, Italy, Holocene, 18, 679-692, 2008.

Colombaroli, D., Beckmann, M., van der Knaap, W. O., Curdy, P., and Tinner, W.: Changes in biodiversity and vegetation composition in the central Swiss Alps during the transition from pristine forest to first farming, Divers. Distrib., 19, 157-170, doi:10.1111/j.1472-4642.2012.00930.x, 2013.

Conedera, M. and Tinner, W.: Long-term fire ecology of Switzerland, Journal forestier suisse, 161, 424-432, 2010.

Conedera, M., Tinner, W., Neff, C., Meurer, M., Dickens, A. F., and Krebs, P.: Reconstructing past fire regimes: methods, applications, and relevance to fire management and conservation, Quaternary Sci. Rev., 28, 555-576, 2009.

Cordeiro, R. C., Turcq, B. J., Moreira, L. S., de Aragão Rodrigues, R., Filho, F. F. L. S., Martins, G. S., Santos, A. B., Barbosa, M., da Conceição, M. C. G., de Carvalho Rodrigues, R., Evangelista, H., Moreira-Turcq, P. F., Penido, Y. P., Sifeddine, A., and Seoane, J. C. S.: Palaeofires in Amazon: Interplay between Land Use Change and Palaeoclimatic Events, Palaeogeogr. Palaeocl., 415, 137-151, doi:10.1016/j.palaeo.2014.07.020, 2014.

Coughlan, M. R. and Petty, A. M.: Linking humans and fire: a proposal for a transdisciplinary fire ecology, Int. J. Wildland Fire, 21, 477-487, 2012.

Courtney Mustaphi, C. J. and Pisaric, M. F. J.: Holocene climatefire-vegetation interactions at a subalpine watershed in southeastern British Columbia, Canada, Quaternary Res., 81, 228239,2014

Cyr, D., Gauthier, S., Bergeron, Y., and Carcaillet, C.: Forest management is driving the eastern North American boreal forest outside its natural range of variability, Front. Ecol. Environ., 7, 519524, 2009

Daniau, A.-L., Harrison, S. P., and Bartlein, P. J.: Fire regimes during the last glacial, Quaternary Sci. Rev., 29, 2918-2930, 2010.

Daniau, A.-L., Goñi, M. F. S., Martinez, P., Urrego, D. H., BoutRoumazeilles, V., Desprat, S., and Marlon, J. R.: Orbital-scale climate forcing of grassland burning in southern Africa, P. Natl. Acad. Sci. USA, 110, 5069-5073, 2013.

Daniau, A. L., Bartlein, P., Harrison, S., Prentice, I., Brewer, S., Friedlingstein, P., Harrisson Prentice, T., Inoue, J., Izumi, K., and Marlon, J.: Predictability of biomass burning in response to climate changes, Global Biogeochem. Cy., 26, GB4007, doi:10.1029/2011GB004249, 2012.
DeBano, L. F.: The role of fire and soil heating on water repellency in wildland environments: a review, J. Hydrol., 231, 195-206, 2000.

Delcourt, P. A., Delcourt, H. R., Ison, C. R., Sharp, W. E., and Gremillion, K. J.: Prehistoric human use of fire, the Eastern Agricultural Complex, and Appalachian oak-chestnut forests: Paleoecology of Cliff Palace Pond, Kentucky, Am. Antiquity, 63, 263278, 1998.

Dennison, P. E., Brewer, S. C., Arnold, J. D., and Moritz, M. A.: Large wildfire trends in the western United States, 1984-2011, Geophys. Res. Lett., 41, 2928-2933, 2014.

Dunnette, P. V., Higuera, P. E., McLauchlan, K. K., Derr, K. M., Briles, C. E., and Keefe, M. H.: Biogeochemical impacts of wildfires over four millennia in a Rocky Mountain subalpine watershed, New Phytol., 203, 900-912, 2014.

Easterbrook, S. M.: Open code for open science?, Nat. Geosci., 7, 779-781, 2014.

Edwards, M., Franklin-Smith, L., Clarke, C., Baker, J., Hill, S., and Gallagher, K.: The role of fire in the mid-Holocene arrival and expansion of lodgepole pine (Pinus contorta var. latifolia Engelm. ex S. Watson) in Yukon, Canada, Holocene, 25, 64-78, 2015.

Enache, M. D. and Cumming, B. F.: Tracking recorded fires using charcoal morphology from the sedimentary sequence of Prosser Lake, British Columbia (Canada), Quaternary Res., 65, 282-292, 2006.

Falk, D. A., Heyerdahl, E. K., Brown, P. M., Farris, C., Fulé, P. Z., McKenzie, D., Swetnam, T. W., Taylor, A. H., and Van Horne, M. L.: Multi-scale controls of historical forest-fire regimes: new insights from fire-scar networks, Front. Ecol. Environ., 9, 446454, 2011.

Fischer, H., Behrens, M., Bock, M., Richter, U., Schmitt, J., Loulergue, L., Chappellaz, J., Spahni, R., Blunier, T., Leuenberger, M., and Stocker, T. F.: Changing boreal methane sources and constant biomass burning during the last termination, Nature, 452 , 864-867, doi:10.1038/nature06825, 2008.

Fuller, J. L., Foster, D. R., McLachlan, J. S., and Drake, N.: Impact of human activity on regional forest composition and dynamics in central New England, Ecosystems, 1, 76-95, 1998.

Ganopolski, A., Petoukhov, V., Rahmstorf, S., Brovkin, V., Claussen, M., Eliseev, A., and Kubatzki, C.: CLIMBER-2: a climate system model of intermediate complexity, Part II: model sensitivity, Clim. Dynam., 17, 735-751, 2001.

Gavin, D. G., Hu, F. S., Lertzman, K., and Corbett, P.: Weak climatic control of stand-scale fire history during the late Holocene, Ecology, 87, 1722-1732, 2006.

Gavin, D. G., Hallett, D. J., Hu, F. S., Lertzman, K. P., Prichard, S. J., Brown, K. J., Lynch, J. A., Bartlein, P., and Peterson, D. L.: Forest fire and climate change in western North America: insights from sediment charcoal records, Front. Ecol. Environ., 5, 499-506, 2007.

Giglio, L., Randerson, J. T., and van der Werf, G. R.: Analysis of daily, monthly, and annual burned area using the fourthgeneration global fire emissions database (GFED4), J. Geophys Res.-Biogeo., 118, 317-328, 2013.

Giorgetta, M. A., Jungclaus, J., Reick, C. H., Legutke, S., Bader, J., Böttinger, M., Brovkin, V., Crueger, T., Esch, M., and Fieg, K.: Climate and carbon cycle changes from 1850 to 2100 in MPI ESM simulations for the Coupled Model Intercomparison 
Project phase 5, Journal of Advances in Modeling Earth Systems, 5, 572-597, 2013.

Girardin, M. P. and Sauchyn, D.: Three centuries of annual area burned variability in northwestern North America inferred from tree rings, Holocene, 18, 205-214, 2008.

Goring, S., Williams, J. W., Blois, J. L., Jackson, S. T., Paciorek, C., Booth, R. K., Marlon, J. R., Blaauw, M., and Andres, C.: Deposition times in the northeastern United States during the Holocene: establishing valid priors for Bayesian age models, Quaternary Sci. Rev., 48, 54-60, 2012.

Gu, Y. S., Pearsall, D. M., Xie, S. C., and Yu, J. X.: Vegetation and fire history of a Chinese site in southern tropical Xishuangbanna derived from phytolith and charcoal records from Holocene sediments, J. Biogeogr., 35, 325-341, 2008.

Haberle, S. G.: Late quaternary vegetation change in the Tari Basin, Papua New Guinea, Palaeogeogr. Palaeocl., 137, 1-24, 1998.

Haberle, S. G. and Ledru, M. P.: Correlations among charcoal records of fires from the past 16000 years in Indonesia, Papua New Guinea, and Central and South America, Quaternary Res., 55, 97-104, 2001.

Hallett, D., Hills, L. V., and Clague, J. J.: New accelerator mass spectrometry radiocarbon ages for the Mazama tephra layer from Kootenay National Park, British Columbia, Canada, Can. J. Earth Sci., 34, 1202-1209, 1997.

Han, Y. M., Marlon, J. R., Cao, J. J., Jin, Z. D., and An, Z. S.: Holocene biomass burning trends in China from soot, char and charcoal in lake sediments, Global Biogeochem. Cy., 26, GB4017, doi:10.1029/2011GB004197, 2012.

Harley, G. L., Grissino-Mayer, H. D., and Horn, S. P.: Fire history and forest structure of an endangered subtropical ecosystem in the Florida Keys, USA, Int. J. Wildland Fire, 104, 1-19, 2012.

Harrison, S. P., Marlon, J. R., and Bartlein, P. J.: Fire in the Earth System, in: Changing Climates, Earth Systems and Society, edited by: Dodson, J., Springer, Dordrecht, The Netherlands, 2010.

Herridge, V., Birch, S. P., and Law, M.: Open Quaternary: A New, Open Access J. Quaternary Res., Open Quaternary, 1, doi:10.5334/oq.ad, 2015.

Heusser, C. J.: Three late Quaternary pollen diagrams from southern Patagonia and their palaeoecological implications, Palaeogeogr. Palaeocl., 118, 1-24, 1995.

Higuera, P., Gavin, D., Bartlein, P., and Hallett, D.: Peak detection in sediment-charcoal records: impacts of alternative data analysis methods on fire-history interpretations, Int. J. Wildland Fire, 19, 996-1014, 2010.

Higuera, P. E., Peters, M. E., Brubaker, L. B., and Gavin, D. G.: Understanding the origin and analysis of sediment-charcoal records with a simulation model, Quaternary Sci. Rev., 26, 1790-1809, 2007.

Higuera, P. E., Whitlock, C., and Gage, J.: Linking tree-ring and sediment-charcoal records to reconstruct fire occurrence and area burned in subalpine forests of Yellowstone National Park, USA, Holocene 21, 327-341, 2011.

Higuera, P. E., Briles, C. E., and Whitlock, C.: Fire-regime complacency and sensitivity to centennial-through millennial-scale climate change in Rocky Mountain subalpine forests, Colorado, USA, J. Ecol., 102, 1429-1441, 2014.
Iglesias, V. and Whitlock, C.: Fire responses to postglacial climate change and human impact in northern Patagonia $\left(41-43^{\circ} \mathrm{S}\right), \mathrm{P}$. Natl. Acad. Sci. USA, 111, E5545-E5554, 2014.

Iglesias, V., Whitlock, C., Bianchi, M. M., Villarosa, G., and Outes, V.: Holocene climate variability and environmental history at the Patagonian forest/steppe ecotone: Lago Mosquito $\left(42^{\circ} 29^{\prime} 37.89^{\prime \prime} \mathrm{S}, 71^{\circ} 24^{\prime} 14.57^{\prime \prime} \mathrm{W}\right)$ and Laguna del Condor $\left(42^{\circ} 20^{\prime} 47.22^{\prime \prime} \mathrm{S}, 71^{\circ} 17^{\prime} 07.62^{\prime \prime} \mathrm{W}\right)$, Holocene, 22, 1297-1307, 2012.

Jensen, K., Lynch, E. A., Calcote, R., and Hotchkiss, S. C.: Interpretation of charcoal morphotypes in sediments from Ferry Lake, Wisconsin, USA: do different plant fuel sources produce distinctive charcoal morphotypes?, Holocene, 17, 907-915, 2007.

Kattge, J., Diaz, S., and Wirth, C.: Of carrots and sticks, Nat. Geosci., 7, 778-779, 2014.

Kehrwald, N., Whitlock, C., Barbante, C., Brovkin, V., Daniau, A.L., Kaplan, J., Marlon, J. R., Power, M. J., Thonicke, K., and Van Der Werf, G. R.: Recent advancements in wildfire research, Eos Trans. AGU, 421-423, 2013.

Kelley, D. I., Harrison, S. P., and Prentice, I. C.: Improved simulation of fire-vegetation interactions in the Land surface Processes and eXchanges dynamic global vegetation model (LPXMv1), Geosci. Model Dev., 7, 2411-2433, doi:10.5194/gmd-72411-2014, 2014.

Kelly, R., Chipman, M. L., Higuera, P. E., Stefanova, I., Brubaker, L. B., and Hu, F. S.: Recent burning of boreal forests exceeds fire regime limits of the past 10000 years, P. Natl. Acad. Sci. USA, 110, 13055-13060, 2013.

Keywood, M., Kanakidou, M., Stohl, A., Dentener, F., Grassi, G., Meyer, C. P., Torseth, K., Edwards, D., Thompson, A. M., Lohmann, U., and Burrows, J.: Fire in the Air: Biomass Burning Impacts in a Changing Climate, Critical Reviews in Environmental Science and Technology, 43, 40-83, 2013.

Kloster, S., Mahowald, N. M., Randerson, J. T., Thornton, P. E., Hoffman, F. M., Levis, S., Lawrence, P. J., Feddema, J. J., Oleson, K. W., and Lawrence, D. M.: Fire dynamics during the 20th century simulated by the Community Land Model, Biogeosciences, 7, 1877-1902, doi:10.5194/bg-7-1877-2010, 2010.

Kloster, S., Mahowald, N. M., Randerson, J. T., and Lawrence, P. J.: The impacts of climate, land use, and demography on fires during the 21 st century simulated by CLM-CN, Biogeosciences, 9, 509-525, doi:10.5194/bg-9-509-2012, 2012.

Kloster, S., Brücher, T., Brovkin, V., and Wilkenskjeld, S.: Controls on fire activity over the Holocene, Clim. Past, 11, 781-788, doi:10.5194/cp-11-781-2015, 2015.

Lamarque, J.-F., Bond, T. C., Eyring, V., Granier, C., Heil, A., Klimont, Z., Lee, D., Liousse, C., Mieville, A., Owen, B., Schultz, M. G., Shindell, D., Smith, S. J., Stehfest, E., Van Aardenne, J., Cooper, O. R., Kainuma, M., Mahowald, N., McConnell, J. R., Naik, V., Riahi, K., and van Vuuren, D. P.: Historical (1850-2000) gridded anthropogenic and biomass burning emissions of reactive gases and aerosols: methodology and application, Atmos. Chem. Phys., 10, 7017-7039, doi:10.5194/acp10-7017-2010, 2010.

Lasslop, G., Thonicke, K., and Kloster, S.: Spitfire within the mpi earth system model: Model development and evaluation, Advances in Modeling Earth Systems, 6, 740-755, 2014.

Le Page, Y., Morton, D., Bond-Lamberty, B., Pereira, J. M. C., and Hurtt, G.: HESFIRE: a global fire model to explore the role of an- 
thropogenic and weather drivers, Biogeosciences, 12, 887-903, doi:10.5194/bg-12-887-2015, 2015.

Lehndorff, E., Wolf, M., Litt, T., Brauer, A., and Amelung, W.: 15000 years of black carbon deposition - A post-glacial fire record from maar lake sediments (Germany), Quaternary Sci. Rev., 110, 15-22, 2015.

Li, F., Levis, S., and Ward, D. S.: Quantifying the role of fire in the Earth system - Part 1: Improved global fire modeling in the Community Earth System Model (CESM1), Biogeosciences, 10, 2293-2314, doi:10.5194/bg-10-2293-2013, 2013.

Maezumi, S. Y., Power, M. J., Mayle, F. E., McLauchlan, K. K., and Iriarte, J.: Effects of past climate variability on fire and vegetation in the cerrãdo savanna of the Huanchaca Mesetta, NE Bolivia, Clim. Past, 11, 835-853, doi:10.5194/cp-11-835-2015, 2015.

Mann, M. E., Zhang, Z., Rutherford, S., Bradley, R. S., Hughes, M. K., Shindell, D., Ammann, C., Faluvegi, G., and Ni, F.: Global signatures and dynamical origins of the Little Ice Age and Medieval Climate Anomaly, Science, 326, 1256-1260, 2009.

Marlon, J., Bartlein, P. J., and Whitlock, C.: Fire-fuel-climate linkages in the northwestern USA during the Holocene, Holocene, 16, 1059-1071, 2006.

Marlon, J., Bartlein, P., Carcaillet, C., Gavin, D. G., Harrison, S. P., Higuera, P. E., Joos, F., Power, M. J., and Prentice, C. I.: Climate and human influences on global biomass burning over the past two millennia, Nat. Geosci., 1, 697-701, 2008.

Marlon, J., Bartlein, P., Walsh, M. K., Harrison, S. P., Brown, K. J., Edwards, M. E., Higuera, P. E., Power, M. J., Anderson, R. S., Briles, C. E., Brunelle, A., Carcaillet, C., Daniels, M., Hu, F. S., Lavoie, M., Long, C. J., Minckley, T., Richard, P. J. H., Scott, A. C., Shafer, D. S., Tinner, W., Umbanhowar Jr, C. E., and Whitlock, C.: Wildfire responses to abrupt climate change in North America, P. Natl. Acad. Sci. USA, 106, 2519-2524, 2009.

Marlon, J. R., Bartlein, P. J., Gavin, D. G., Long, C. J., Anderson, R. S., Briles, C. E., Brown, K. J., Colombaroli, D., Hallett, D. J., Power, M. J., Scharf, E. A., and Walsh, M. K.: Long-term perspective on wildfires in the western USA, P. Natl. Acad. Sci. USA, 109, E535-E543, 2012.

Marlon, J. R., Bartlein, P. J., Daniau, A.-L., Harrison, S. P., Maezumi, S. Y., Power, M. J., Tinner, W., and Vanniere, B.: Global biomass burning: a synthesis and review of Holocene paleofire records and their controls, Quaternary Sci. Rev., 65, 5-25, 2013.

Martin Calvo, M., Prentice, I. C., and Harrison, S. P.: Climate versus carbon dioxide controls on biomass burning: a model analysis of the glacial-interglacial contrast, Biogeosciences, 11, 6017-6027, doi:10.5194/bg-11-6017-2014, 2014.

McConnell, J. R., Edwards, R., Kok, G. L., Flanner, M. G., Zender, C. S., Saltzman, E. S., Banta, J. R., Pasteris, D. R., Carter, M. M., and Kahl, J. D. W.: 20th-century industrial black carbon emissions altered Arctic climate forcing, Science, 317, 1381-1384, 2007.

McLauchlan, K. K., Higuera, P. E., Gavin, D. G., Perakis, S. S., Mack, M. C., Alexander, H., Battles, J., Biondi, F., Buma, B., Colombaroli, D., Enders, S. K., Engstrom, D. R., Hu, F. S., Marlon, J. R., Marshall, J., McGlone, M., Morris, J. L., Nave, L. E., Shuman, B., Smithwick, E. A. H., Urrego, D. H., Wardle, D. A., Williams, C. J., and Williams, J. J.: Reconstructing Disturbances and Their Biogeochemical Consequences over Multiple Timescales, BioScience, 64, 105-116, 2014.
McWethy, D. B., Higuera, P. E., Whitlock, C., Veblen, T. T., Bowman, D. M. J. S., Cary, G. J., Haberle, S. G., Keane, R. E., Maxwell, B. D., McGlone, M. S., Perry, G. L. W., Wilmshurst, J. M., Holz, A., and Tepley, A. J.: A conceptual framework for predicting temperate ecosystem sensitivity to human impacts on fire regimes, Glob. Ecol. Biogeogr., 22, 900-912, 2013.

Mooney, S. D., Harrison, S. P., Bartlein, P. J., A.-L., D., Stevenson, J., Brownlie, K. C., Buckman, S., Cupper, M., Luly, J., Black, M., Colhoun, E., D’Costa, D., Dodson, J., Haberle, S., Hope, G. S., Kershaw, P., Kenyon, C., McKenzie, M., and Williams, N.: Late Quaternary fire regimes of Australasia, Quaternary Sci. Rev., 30, 28-46, 2011.

Moos, M. T. and Cumming, B. F.: Climate-fire interactions during the Holocene: a test of the utility of charcoal morphotypes in a sediment core from the boreal region of north-western Ontario (Canada), Int. J. Wildland Fire, 21, 640-652, 2012.

Morris, S. E. and Moses, T. A.: Forest fire and the natural soil erosion regime in the Colorado Front Range, Ann. Assoc. Am. Geogr., 77, 245-254, 1987.

Mouillot, F. and Field, C. B.: Fire history and the global carbon budget: a $1^{\circ} \times 1^{\circ}$ fire history reconstruction for the 20th century, Glob. Change Biol., 11, 398-420, 2005.

Mouillot, F., Narasimha, A., Balkanski, Y., Lamarque, J.-F., and Field, C. B.: Global carbon emissions from biomass burning in the 20th century, Geophys. Res. Lett., 33, L01801, doi:10.1029/2005GL024707, 2006.

Mouillot, F., Schultz, M. G., Yue, C., Cadule, P., Tansey, K., Ciais, P., and Chuvieco, E.: Ten years of global burned area products from spaceborne remote sensing : a review : analysis of user needs and recommendations for future developments, Int. J. Appl. Earth Obs., 26, 64-79, 2014.

Munoz, S. E., Mladenoff, D. J., Schroeder, S., and Williams, J. W.: Defining the spatial patterns of historical land use associated with the indigenous societies of eastern North America, J. Biogeogr., 41, 2195-2210, 2014.

Mustaphi, C. J. C. and Pisaric, M. F. J.: A classification for macroscopic charcoal morphologies found in Holocene lacustrine sediments, Prog. Phys. Geogr., 38, 734-754, 2014.

Neumann, F. H., Botha, G. A., and Scott, L.: 18000 years of grassland evolution in the summer rainfall region of South Africa: evidence from Mahwaqa Mountain, KwaZulu-Natal, Veg. Hist. Archaeobot., 23, 665-681, 2014.

Pechony, O. and Shindell, D. T.: Fire parameterization on a global scale, J. Geophys. Res., 114, 1-10, 2009.

Pechony, O. and Shindell, D.: Driving forces of global wildfires over the past millennium and the forthcoming century, P. Natl. Acad. Sci. USA, 107, 19167-19170, doi:10.1073/pnas.1003669107, 2010.

Perry, G. L. W., Wilmshurst, J. M., McGlone, M. S., McWethy, D. B., and Whitlock, C.: Explaining fire-driven landscape transformation during the Initial Burning Period of New Zealand's prehistory, Glob. Change Biol., 18, 1609-1621, 2012.

Petoukhov, V., Ganopolski, A., Brovkin, V., Claussen, M., Eliseev, A., Kubatzki, C., and Rahmstorf, S.: CLIMBER-2: a climate system model of intermediate complexity, Part I: model description and performance for present climate, Clim. Dynam., 16, 1-17, 2000.

Pfeiffer, M., Spessa, A., and Kaplan, J. O.: A model for global biomass burning in preindustrial time: LPJ-LMfire (v1.0), 
Geosci. Model Dev., 6, 643-685, doi:10.5194/gmd-6-643-2013, 2013.

Pierce, J., Meyer, G., and Jull, A.: Fire-induced erosion and millennial-scale climate change in northern ponderosa pine forests, Nature, 432, 87-90, 2004.

Power, M. J., Marlon, J., Ortiz, N., Bartlein, P. J., Harrison, S. P., Mayle, F. E., Ballouche, A., Bradshaw, R. H. W., Carcaillet, C., Cordova, C., Mooney, S., Moreno, P. I., Prentice, I. C., Thonicke, K., Tinner, W., Whitlock, C., Zhang, Y., Zhao, Y., Ali, A. A., Anderson, R. S., Beer, R., Behling, H., Briles, C., Brown, K. J., Brunelle, A., Bush, M., Camill, P., Chu, G. Q., Clark, J., Colombaroli, D., Connor, S., Daniau, A.-L., Daniels, M., Dodson, J., Doughty, E., Edwards, M. E., Finsinger, W., Foster, D., Frechette, J., Gaillard, M.-J., Gavin, D. G., Gobet, E., Haberle, S., Hallett, D. J., Higuera, P., Hope, G., Horn, S., Inoue, J., Kaltenrieder, P., Kennedy, L., Kong, Z. C., Larsen, C., Long, C. J., Lynch, J., Lynch, E. A., McGlone, M., Meeks, S., Mensing, S., Meyer, G., Minckley, T., Mohr, J., Nelson, D. M., New, J., Newnham, R., Noti, R., Oswald, W., Pierce, J., Richard, P. J. H., Rowe, C., Goñi, M. F. S., Shuman, B. N., Takahara, H., Toney, J., Turney, C., Urrego-Sanchez, D. H., Umbanhowar, C., Vandergoes, M., Vanniere, B., Vescovi, E., Walsh, M., Wang, X., Williams, N., Wilmshurst, J., and Zhang, J. H.: Changes in fire regimes since the Last Glacial Maximum: An assessment based on a global synthesis and analysis of charcoal data, Clim. Dynam., 30, 887907, 2008

Power, M. J., Marlon, J. R., Bartlein, P. J., and Harrison, S. P.: Fire history and the Global Charcoal Database: A new tool for hypothesis testing and data exploration, Palaeogeogr. Palaeocl., 291, 52-59, 2010.

Power, M. J., Mayle, F. E., Bartlein, P. J., Marlon, J. R., Anderson, R. S., Behling, H., Brown, K. J., Carcaillet, C., Colombaroli, D., Gavin, D. G., Hallett, D. J., Horn, S. P., Kennedy, L. M., Lane, C. S., Long, C. J., Moreno, P. I., Paitre, C., Robinson, G., Taylor, Z., and Walsh, M. K.: Climatic control of the biomass-burning decline in the Americas after AD 1500, Holocene, 23, 3-13, 2012.

Quintana-Krupinski, N., Marlon, J. R., Nishri, A., Street, J. H., and Paytan, A.: Climatic and human controls on the late Holocene fire history of northern Israel, Quaternary Res., 80, 396-405, 2013.

R Development Core Team: R: A language and environment for statistical computing, Vienna, Austria, 2013.

Raddatz, T., Reick, C., Knorr, W., Kattge, J., Roeckner, E., Schnur, R., Schnitzler, K.-G., Wetzel, P., and Jungclaus, J.: Will the tropical land biosphere dominate the climate-carbon cycle feedback during the twenty-first century?, Clim. Dynam., 29, 565-574, 2007.

Randerson, J. T., Liu, H., Flanner, M. G., Chambers, S. D., Jin, Y., Hess, P. G., Pfister, G., Mack, M. C., Treseder, K. K., Welp, L. R., Chapin, F. S., Harden, J. W., Goulden, M. L., Lyons, E., Neff, J. C., Schuur, E. A. G., and Zender, C. S.: The impact of boreal forest fire on climate warming, Science, 314, 1130-1132, 2006.

Reick, C., Raddatz, T., Brovkin, V., and Gayler, V.: Representation of natural and anthropogenic land cover change in MPI ESM, Journal of Advances in Modeling Earth Systems, 5, 459-482, 2013.

Saleh, R., Robinson, E. S., Tkacik, D. S., Ahern, A. T., Liu, S., Aiken, A. C., Sullivan, R. C., Presto, A. A., Dubey, M. K., Yokelson, R. J., Donahue, N. M., and Robinson, A. L.: Brownness of organics in aerosols from biomass burning linked to their black carbon content, Nat. Geosci., 7, 647-650, 2014.

Savarino, J. and Legrand, M.: High northern latitude forest fires and vegetation emissions over the last millennium inferred from the chemistry of a central Greenlabd ice core, J. Geophys. Res., 103, 8267-8279, 1998.

Schneck, R., Reick, C. H., and Raddatz, T.: Land contribution to natural $\mathrm{CO}_{2}$ variability on time scales of centuries, Journal of Advances in Modeling Earth Systems, 5, 354-365, 2013.

Shakesby, R. A. and Doerr, S. H.: Wildfire as a hydrological and geomorphological agent, Earth-Sci. Rev., 74, 269-307, 2006.

Swain, A. M.: A History of Fire and Vegetation in Northeastern Minnesota as Recorded in Lake Sediments, Quaternary Res., 3, 383-396, 1973.

Tan, Z. and Huang, C. C.: Holocene wildfire history in loess tableland in the middle reaches of the Yellow River of China, Holocene, 23, 1466-1476, 2013.

Thevenon, F. and Anselmetti, F. S.: Charcoal and fly-ash particles from Lake Lucerne sediments (Central Switzerland) characterized by image analysis: anthropologic, stratigraphic and environmental implications, Quaternary Sci. Rev., 26, 2631-2643, 2007.

Thonicke, K., Spessa, A., Prentice, I. C., Harrison, S. P., Dong, L., and Carmona-Moreno, C.: The influence of vegetation, fire spread and fire behaviour on biomass burning and trace gas emissions: results from a process-based model, Biogeosciences, 7, 1991-2011, doi:10.5194/bg-7-1991-2010, 2010.

Tinner, W., Hofstetter, S., Zeugin, F., Conedera, M., Wohlgemuth, T., Zimmermann, L., and Zweifel, R.: Long-distance transport of macroscopic charcoal by an intensive crown fire in the Swiss Alps - implications for fire history reconstruction, Holocene, 16, 287-292, 2006.

Tweiten, M. A., Hotchkiss, S. C., Booth, R. K., Calcote, R. R., and Lynch, E. A.: The response of a jack pine forest to late-Holocene climate variability in northwestern Wisconsin, Holocene, 19, 1049-1061, 2009.

van der Werf, G. R., Randerson, J. T., Giglio, L., Collatz, G. J., Kasibhatla, P. S., and Arellano Jr., A. F.: Interannual variability in global biomass burning emissions from 1997 to 2004, Atmos. Chem. Phys., 6, 3423-3441, doi:10.5194/acp-6-3423-2006, 2006.

van der Werf, G. R., Randerson, J. T., Giglio, L., Collatz, G. J., Mu, M., Kasibhatla, P. S., Morton, D. C., DeFries, R. S., Jin, Y., and van Leeuwen, T. T.: Global fire emissions and the contribution of deforestation, savanna, forest, agricultural, and peat fires (19972009), Atmos. Chem. Phys., 10, 11707-11735, doi:10.5194/acp10-11707-2010, 2010.

Vanniere, B., Colombaroli, D., Chapron, E., Leroux, A., Tinner, W., and Magny, M.: Climate versus human-driven fire regimes in Mediterranean landscapes: the Holocene record of Lago dell'Accesa (Tuscany, Italy), Quaternary Sci. Rev., 27, 11811196, 2008.

Vanniere, B., Power, M. J., Roberts, N., Tinner, W., Carrión, J., Magny, M., Bartlein, P., Colombaroli, D., Daniau, A. L., Finsinger, W., Gil-Romera, G., Kaltenrieder, P., Pini, R., Sadori, L., Turner, R., Valsecchi, V., and Vescovi, E.: CircumMediterranean fire activity and climate changes during the mid-Holocene environmental transition (8500-2500 cal. BP), Holocene, 21, 53-73, 2011. 
Verardo, D. J., Froelich, P. N., and McIntyre, A.: Determination of organic carbon and nitrogen in marine sediments using the Carlo Erba NA-1500 Analyzer, Deep-Sea Res. Pt. I, 37, 157$165,1990$.

Walsh, M. K., Whitlock, C., and Bartlein, P. J.: A 14 300-year-long record of fire-vegetation-climate linkages at Battle Ground Lake, southwestern Washington, Quaternary Res., 70, 251-264, 2008.

Walsh, M. K., Marlon, J. R., Goring, S. J., Brown, K. J., and Gavin, D. G.: A Regional Perspective on Holocene Fire-ClimateHuman Interactions in the Pacific Northwest of North America, Ann. Assoc. Am. Geogr., 105, 1135-1157, 2015.

Wang, Z., Chappellaz, J., Park, K., and Mak, J. E.: Large variations in southern hemisphere biomass burning during the last 650 years, Science, 330, 1663-1666, 2010.

Ward, D. S., Kloster, S., Mahowald, N. M., Rogers, B. M., Randerson, J. T., and Hess, P. G.: The changing radiative forcing of fires: global model estimates for past, present and future, Atmos. Chem. Phys., 12, 10857-10886, doi:10.5194/acp12-10857-2012, 2012.

Whitlock, C. and Bartlein, P. J.: Holocene fire activity as a record of past environmental change, in: Developments in Quaternary Science, edited by: Gillespie, A. R., Porter, S. C., and Atwater, B. F., Elsevier, Amsterdam, 2004.

Whitlock, C., Shafer, S. L., and Marlon, J.: The role of climate and vegetation change in shaping past and future fire regimes in the northwestern US and the implications for ecosystem management, Forest Ecol. Manag., 178, 5-21, 2003.

Whitlock, C., Moreno, P. I., and Bartlein, P.: Climatic controls of Holocene fire patterns in southern South America, Quaternary Res., 68, 28-36, 2007.
Williams, A. N., Mooney, S. D., Sisson, S. A., and Marlon, J.: Exploring the relationship between Aboriginal population indices and fire in Australia over the last 20000 years, Palaeogeogr. Palaeocl., 432, 49-57, 2015.

Winkler, M. G.: Charcoal analysis for paleoenvironmental interpretation: a chemical assay, Quaternary Res., 23, 313-326, 1985.

Wooller, M. J., Street-Perrott, F. A., and Agnew, A. D. Q.: Late Quaternary fires and grassland palaeoecology of Mount Kenya, East Africa: evidence from charred grass cuticles in lake sediments, Palaeogeogr. Palaeocl., 164, 207-230, 2000.

Yue, C., Ciais, P., Cadule, P., Thonicke, K., Archibald, S., Poulter, B., Hao, W. M., Hantson, S., Mouillot, F., Friedlingstein, P., Maignan, F., and Viovy, N.: Modelling the role of fires in the terrestrial carbon balance by incorporating SPITFIRE into the global vegetation model ORCHIDEE - Part 1: simulating historical global burned area and fire regimes, Geosci. Model Dev., 7, 2747-2767, doi:10.5194/gmd-7-2747-2014, 2014.

Zdanowicz, C. M., Zielinski, G. A., and Germani, M. S.: Mount Mazama eruption: Calendrical age verified and atmospheric impact assessed, Geology, 27, 621-624, 1999.

Zennaro, P., Kehrwald, N., McConnell, J. R., Schüpbach, S., Maselli, O. J., Marlon, J., Vallelonga, P., Leuenberger, D., Zangrando, R., Spolaor, A., Borrotti, M., Barbaro, E., Gambaro, A., and Barbante, C.: Fire in ice: two millennia of boreal forest fire history from the Greenland NEEM ice core, Clim. Past, 10, 1905-1924, doi:10.5194/cp-10-1905-2014, 2014. 